Review

\title{
Vitamin D-Effects on Skeletal and Extraskeletal Health and the Need for Supplementation
}

\author{
Matthias Wacker and Michael F. Holick * \\ Vitamin D, Skin and Bone Research Laboratory, Section of Endocrinology, Nutrition, and Diabetes, \\ Department of Medicine, Boston University Medical Center, 85 East Newton Street, M-1013, Boston, \\ MA 02118, USA; E-Mail: mwacker@bu.edu \\ * Author to whom correspondence should be addressed; E-Mail: mfholick@bu.edu; \\ Tel.: +1-617-638-4546; Fax: +1-617-638-8882.
}

Received: 15 October 2012; in revised form: 21 November 2012 / Accepted: 13 December 2012 / Published: 10 January 2013

\begin{abstract}
Vitamin D, the sunshine vitamin, has received a lot of attention recently as a result of a meteoric rise in the number of publications showing that vitamin D plays a crucial role in a plethora of physiological functions and associating vitamin D deficiency with many acute and chronic illnesses including disorders of calcium metabolism, autoimmune diseases, some cancers, type 2 diabetes mellitus, cardiovascular disease and infectious diseases. Vitamin D deficiency is now recognized as a global pandemic. The major cause for vitamin D deficiency is the lack of appreciation that sun exposure has been and continues to be the major source of vitamin D for children and adults of all ages. Vitamin D plays a crucial role in the development and maintenance of a healthy skeleton throughout life. There remains some controversy regarding what blood level of 25-hydroxyvitamin D should be attained for both bone health and reducing risk for vitamin $\mathrm{D}$ deficiency associated acute and chronic diseases and how much vitamin $\mathrm{D}$ should be supplemented.
\end{abstract}

Keywords: vitamin D; 25-hydroxyvitamin D; vitamin D deficiency; osteoporosis; fractures; cancer; type 2 diabetes mellitus; cardiovascular diseases; autoimmune diseases; infectious diseases 


\section{Introduction}

Vitamin D has been produced by phytoplankton for more than 500 million years [1] and is thought to be the oldest of all hormones whose function initially could have been the protection of ultraviolet-sensitive macromolecules including proteins, DNA and RNA, when these early forms of life were exposed to sunlight for photosynthesis. Later, after the evolution of ocean dwelling animals with vertebral skeletons ventured onto land, the maintenance of calcium homeostasis was a major physiological problem (as opposed to living in the calcium-rich ocean). It was vitamin D that ensured the efficient intestinal calcium absorption from dietary sources and ultimately was essential for the development and maintenance of a calcified mammalian skeleton [2]. Obtaining vitamin D from either sunlight or diet is still critical for most vertebrates for their skeletal health [1,3-5]. Over time, vitamin $\mathrm{D}$ has evolved into a hormone having numerous extraskeletal effects by regulating up to estimated 2000 genes [6,7].

Ethnical and gender differences in skin pigmentation indicate the evolutionary importance of a sufficient vitamin D supply. The varying degrees of depigmentation that evolved in order to permit UVB-induced synthesis of previtamin $\mathrm{D}_{3}$ when hominids migrated outside the tropics can be considered as a compromise solution to the conflicting physiological requirements of vitamin D synthesis and photoprotection that differ depending on latitude and thus warrant different degrees of skin pigmentation. An evolutionary selection pressure towards a lighter skin coloration going along with a higher ability to produce vitamin $\mathrm{D}$ seems not only to be exerted by living in geographic regions with a lower UV intensity but also by being female. Gender differences in skin pigmentation with females being lighter skinned than males in all populations for which data about the skin reflectance was available could be explained by the higher needs of vitamin D during pregnancy and lactation [8].

\section{Vitamin D-Sources}

The main sources of vitamin D are sunlight, supplements and diet [7] (Table 1).

Table 1. Sources of vitamin $D_{2}$ and vitamin $D_{3}$ [7]. Note: This table is modified and reproduced with permission from [7], Copyright (C) 2007 Massachusetts Medical Society.

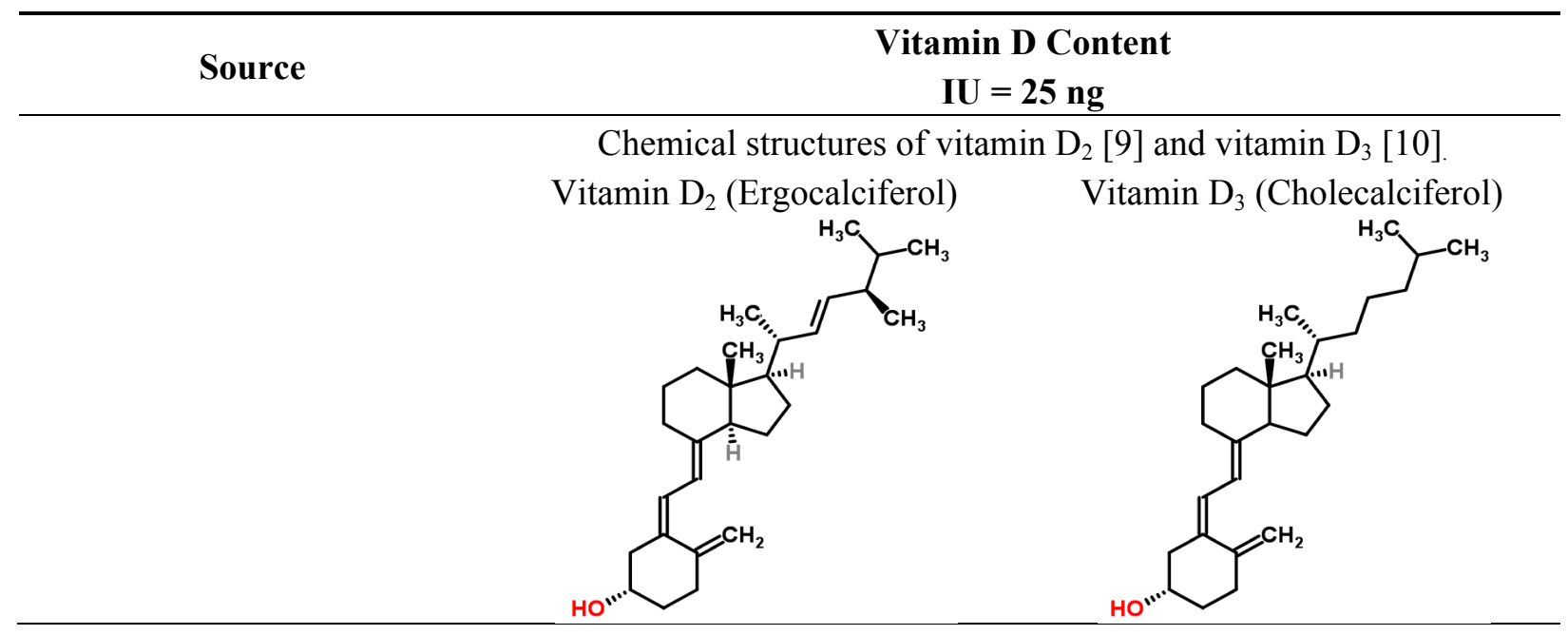


Table 1. Cont.

\begin{tabular}{|c|c|}
\hline \multicolumn{2}{|l|}{ Natural sources } \\
\hline Cod liver oil & $\sim 400-1000 \mathrm{IU} / \mathrm{tsp}$ vitamin $\mathrm{D}_{3}$ \\
\hline Egg yolk & $\sim 20 \mathrm{IU} /$ yolk vitamin $\mathrm{D}_{3}$ or $\mathrm{D}_{2}$ \\
\hline Mackerel, canned & $\sim 250 \mathrm{IU} / 3.5 \mathrm{oz}$ vitamin $\mathrm{D}_{3}$ \\
\hline Salmon, canned & $\sim 300-600 \mathrm{IU} / 3.5 \mathrm{oz}$ vitamin $\mathrm{D}_{3}$ \\
\hline Salmon, fresh farmed & $\sim 100-250 \mathrm{IU} / 3.5$ oz vitamin $\mathrm{D}_{3}$, vitamin $\mathrm{D}_{2}$ \\
\hline Sardines, canned & $\sim 300 \mathrm{IU} / 3.5 \mathrm{oz}$ vitamin $\mathrm{D}_{3}$ \\
\hline Shiitake mushrooms, fresh & $\sim 100 \mathrm{IU} / 3.5 \mathrm{oz}$ vitamin $\mathrm{D}_{2}$ \\
\hline \multicolumn{2}{|c|}{ Shiitake mushrooms, sun dried $\sim 1600 \mathrm{IU} / 3.5 \mathrm{oz}$ vitamin $\mathrm{D}_{2}$} \\
\hline Sunlight/UVB radiation & $\begin{array}{l}\sim 20,000 \text { IU equivalent to exposure to } 1 \text { minimal erythemal dose (MED) } \\
\text { in a bathing suit. Thus, exposure of arms and legs to } 0.5 \mathrm{MED} \text { is } \\
\text { equivalent to ingesting } \sim 3000 \mathrm{IU} \text { vitamin } \mathrm{D}_{3}\end{array}$ \\
\hline Tuna, canned & $236 \mathrm{IU} / 3.5 \mathrm{oz}$ vitamin $\mathrm{D}_{3}$ \\
\hline \multicolumn{2}{|l|}{ Fortified foods } \\
\hline Fortified breakfast cereals & $\sim 100 \mathrm{IU} /$ serving usually vitamin $\mathrm{D}_{3}$ \\
\hline Fortified butter & $56 \mathrm{IU} / 3.5 \mathrm{oz}$ usually vitamin $\mathrm{D}_{3}$ \\
\hline Fortified cheeses & $100 \mathrm{IU} / 3$ oz usually vitamin $\mathrm{D}_{3}$ \\
\hline Fortified margarine & $429 / 3.5$ oz usually vitamin $D_{3}$ \\
\hline Fortified milk & $100 \mathrm{IU} / 8 \mathrm{oz}$ usually vitamin $\mathrm{D}_{3}$ \\
\hline Fortified orange juice & $100 \mathrm{IU} / 8$ oz vitamin $\mathrm{D}_{3}$ \\
\hline Fortified yogurts & $100 \mathrm{IU} / 8 \mathrm{oz}$ usually vitamin $\mathrm{D}_{3}$ \\
\hline Infant formulas & $100 \mathrm{IU} / 8 \mathrm{oz}$ vitamin $\mathrm{D}_{3}$ \\
\hline \multicolumn{2}{|c|}{ Pharmaceutical Sources in the } \\
\hline \multicolumn{2}{|l|}{ United States } \\
\hline Drisdol (vitamin $\mathrm{D}_{2}$ ) liquid & $8000 \mathrm{IU} / \mathrm{mL}$ \\
\hline Vitamin $\mathrm{D}_{2}$ (Ergocalciferol) & $50,000 \mathrm{IU} /$ capsule \\
\hline \multicolumn{2}{|l|}{ Supplemental Sources } \\
\hline Multivitamin & 400,500, and $1000 \mathrm{IU}$ vitamin $\mathrm{D}_{3}$ or vitamin $\mathrm{D}_{2}$ \\
\hline Vitamin $\mathrm{D}_{3}$ & $400,800,1000,2000,5000,10,000,14,000$, and $50,000 \mathrm{IU}$ \\
\hline
\end{tabular}

Exposure of human skin to solar UVB radiation (wavelengths: 290-315 nm) leads to the conversion of 7-dehydrocholesterol to previtamin $\mathrm{D}_{3}$ in the skin. Previtamin $\mathrm{D}_{3}$ is then rapidly converted to vitamin $\mathrm{D}_{3}$ (cholecalciferol) by temperature- and membrane-dependent processes $[7,11,12]$ (Figure 1 ).

Figure 1. Schematic representation of the synthesis and metabolism of vitamin D for regulating calcium, phosphorus and bone metabolism [7]. During exposure to sunlight, 7-dehydrocholesterol in the skin is converted to previtamin $\mathrm{D}_{3}$. Previtamin $\mathrm{D}_{3}$ immediately converts by a heat dependent process to vitamin $D_{3}[7,11,12]$. Excessive exposure to sunlight degrades previtamin $\mathrm{D}_{3}$ and vitamin $\mathrm{D}_{3}$ into inactive photoproducts [13]. Vitamin $\mathrm{D}_{2}$ and vitamin $\mathrm{D}_{3}$ from dietary sources is incorporated into chylomicrons, transported by the lymphatic system into the venous circulation [14]. Vitamin D (D represents $\mathrm{D}_{2}$ or $\mathrm{D}_{3}$ ) made in the skin or ingested in the diet can be stored in and then released from fat cells. Vitamin D in the circulation is bound to the vitamin D binding protein which transports it to the liver where vitamin $\mathrm{D}$ is converted by the vitamin $\mathrm{D}$-25-hydroxylase to 
25-hydroxyvitamin $\mathrm{D}[25(\mathrm{OH}) \mathrm{D}]$. This is the major circulating form of vitamin $\mathrm{D}$ that is used by clinicians to measure vitamin D status [7,15] (although most reference laboratories report the normal range to be $20-100 \mathrm{ng} / \mathrm{mL}$, the preferred healthful range is $30-60 \mathrm{ng} / \mathrm{mL}$ ) [7]. It is biologically inactive and must be converted in the kidneys by the 25-hydroxyvitamin D-1 $\alpha$-hydroxylase (1-OHase) to its biologically active form 1,25-dihydroxyvitamin D [1,25(OH $\left.)_{2} \mathrm{D}\right]$ [7,15-17]. Serum phosphorus, calcium, fibroblast growth factors (FGF-23) and other factors can either increase $(+)$ or decrease $(-)$ the renal production of $1,25(\mathrm{OH})_{2} \mathrm{D}$ [7]. $1,25(\mathrm{OH})_{2} \mathrm{D}$ feedback regulates its own synthesis and decreases the synthesis and secretion of parathyroid hormone (PTH) in the parathyroid glands [6,7]. $1,25(\mathrm{OH})_{2} \mathrm{D}$ increases the expression of the 25-hydroxyvitamin D-24-hydroxylase (24-OHase) to catabolize $1,25(\mathrm{OH})_{2} \mathrm{D}$ to the water soluble biologically inactive calcitroic acid which is excreted in the bile $[7,18]$. $1,25(\mathrm{OH})_{2} \mathrm{D}$ enhances intestinal calcium absorption in the small intestine by stimulating the expression of the epithelial calcium channel $(\mathrm{ECaC})$ and the calbindin $9 \mathrm{~K}$ (calcium binding protein; $\mathrm{CaBP})[7,19,20] .1,25(\mathrm{OH})_{2} \mathrm{D}$ is recognized by its receptor in osteoblasts causing an increase in the expression of receptor activator of NFאB ligand (RANKL). Its receptor RANK on the preosteoclast binds RANKL which induces the preosteoclast to become a mature osteoclast. The mature osteoclast removes calcium and phosphorus from the bone to maintain blood calcium and phosphorus levels [7,17]. Adequate calcium and phosphorus levels promote the mineralization of the skeleton [7]. Note: This figure is reproduced with permission from [21], Copyright (C) 2007 Michael F. Holick.

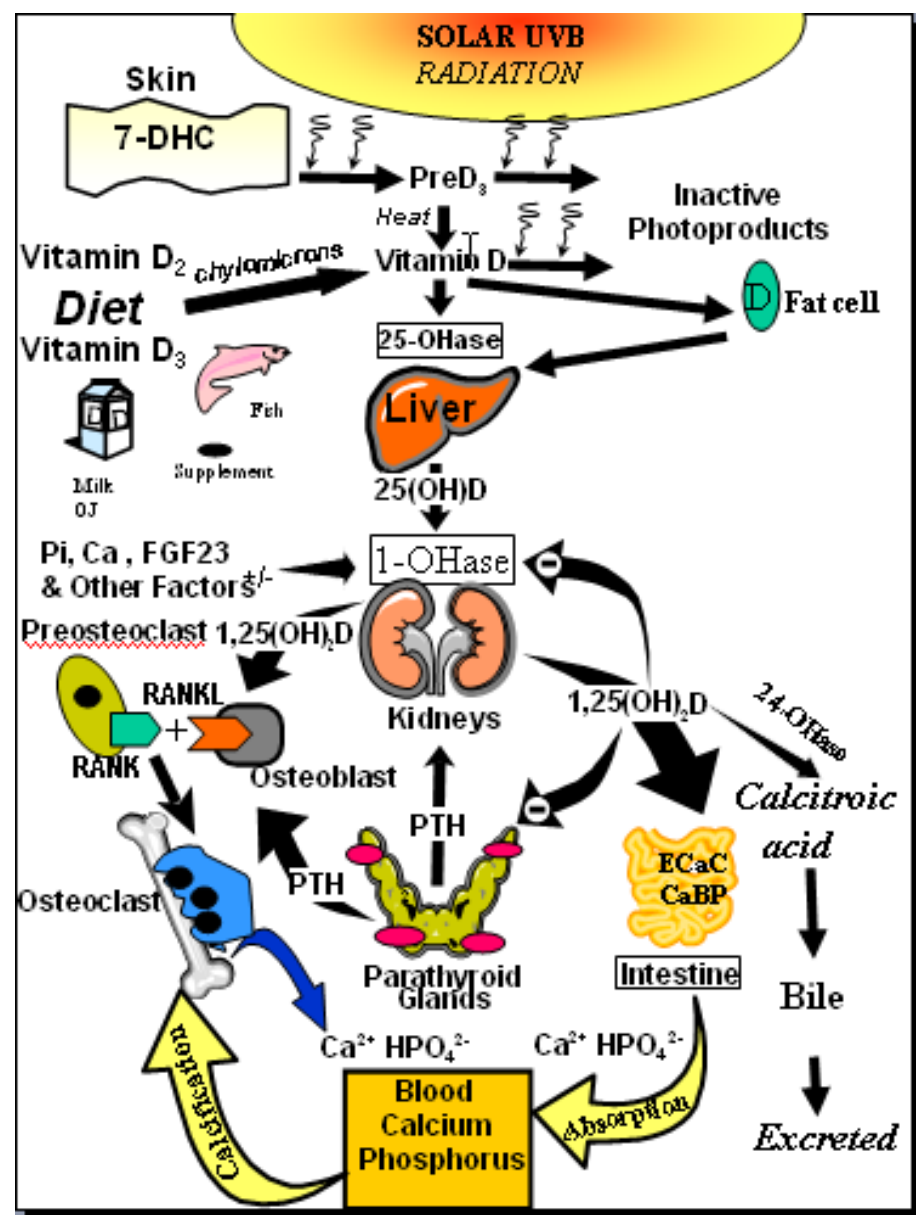


The amount of vitamin D production in the skin depends on the incident angle of the sun and thus on latitude, season and time of the day. It is highest when the sun is in the zenith and a flattening of the incident angle leads to a reduced vitamin D production [17]. Whole body exposure to sunlight with one minimal erythema dose (MED), i.e., the minimal dose leading to pink coloration of the skin $24 \mathrm{~h}$ after exposure, leads to vitamin D levels comparable to oral intake of 10,000 to up to 25,000 IU vitamin $\mathrm{D}_{2}$ [16,22]. However, sun exposure during most of the winter at latitudes above and below $\sim 33$ degrees North and South, respectively, doesn't lead to any production of vitamin $\mathrm{D}_{3}$ in the skin [16,23] (Figure 2). Other factors influencing the cutaneous vitamin D production adversely are an increase in skin pigmentation, aging, especially age $>65$ years and the topical application of a sunscreen [17].

Figure 2. Influence of season, time of day, and latitude on the synthesis of previtamin $\mathrm{D}_{3}$ in Northern (A and $\mathbf{C}$ ) and Southern hemispheres (B and D). The hour indicated in $\mathbf{C}$ and D is the end of the 1-h exposure time. Note: This figure is reproduced with permission from [13], Copyright (C) 2010 Humana Press.
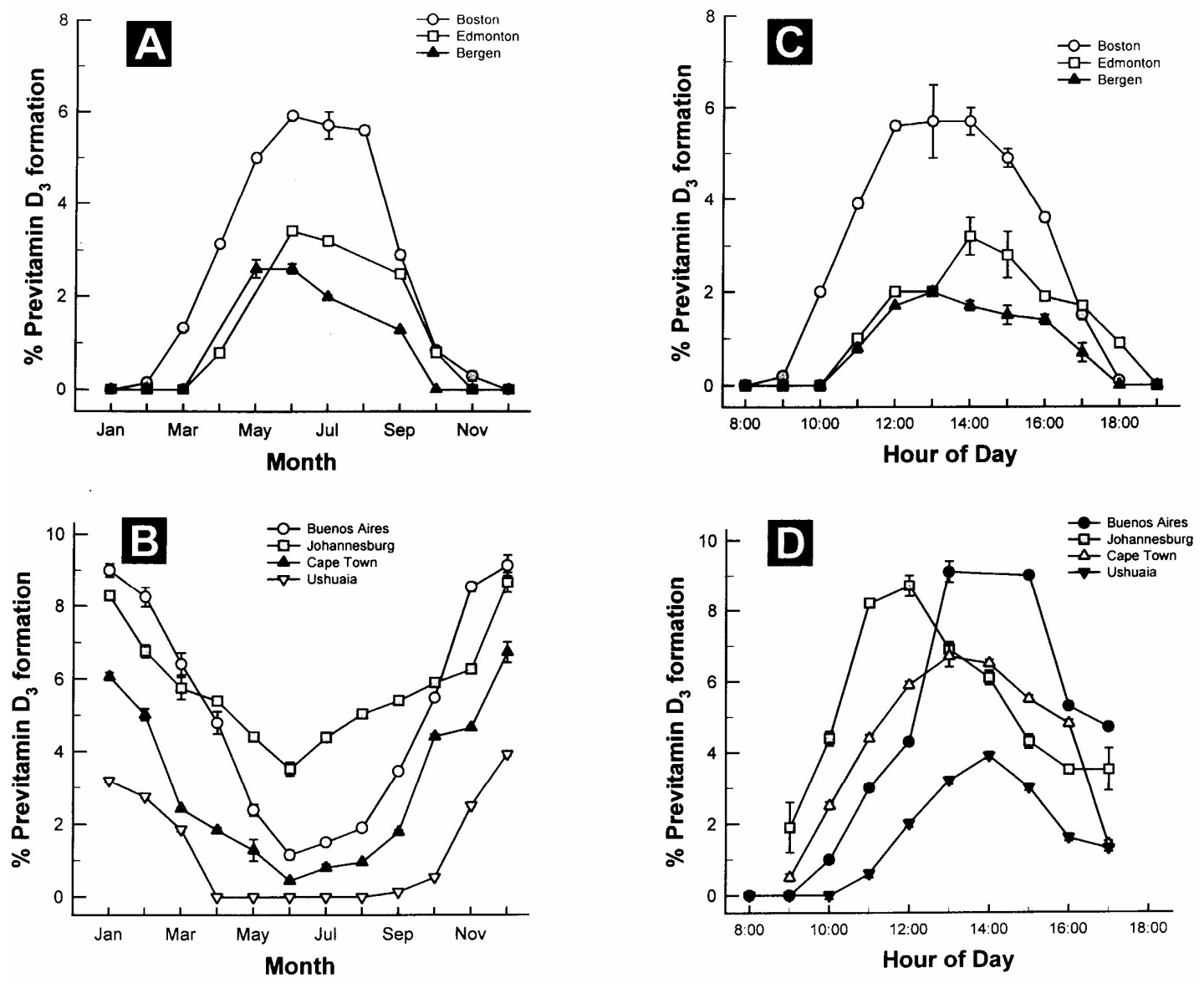

The number of foods naturally containing vitamin D in significant amounts is very limited. Among these are oily fish such as salmon, sardines and tuna, and oils of the liver of some fish such as cod as well as sun-exposed mushrooms [7] (Table 1). To increase the content of vitamin $\mathrm{D}_{2}$ in mushrooms producers are irradiating them with UV radiation [24,25].

In the 1930s, the fortification of milk, sodas, bread and even beer became popular [26]; however, after several cases of presumed vitamin D intoxication in infants in the 1950s in Great Britain [27] 
strict regulations limiting vitamin D fortification to only margarine were introduced in Europe [14,28]. Due to a relatively high prevalence of lactose intolerance leading to an avoidance of milk by many adults, the fortification of orange juice in the US was introduced as a novel approach of enhancing the vitamin D status of the public in the 2003 and proved to be as effective as oral supplementation [26,29]. Other fortified foods include margarine, yogurt, infant formula, butter, cheese and breakfast cereals [7] (Table 1).

Vitamin $\mathrm{D}_{2}$ and vitamin $\mathrm{D}_{3}$ are available as oral over-the-counter supplements. In the US, only vitamin $\mathrm{D}_{2}$ is available as prescription drug [7,17]. Although there has been debate as to whether vitamin $D_{2}$ is as effective as vitamin $D_{3}$ in maintaining vitamin $D$ status [30-36], other studies in children and adults have demonstrated that they are equally effective [29,37-40].

\section{Vitamin D-Metabolism}

Vitamin D from cutaneous synthesis or dietary/supplemental intake, is transported to the fat where it can be stored or to the liver for the first step of activation, the hydroxylation to 25-hydroxyvitamin D [25(OH)D], which is the major circulating form of vitamin D $[7,15]$ and measured to assess a patient's vitamin D status [7,16,41,42] (Figure 1).

$25(\mathrm{OH}) \mathrm{D}$ is metabolized in the kidneys by the mitochondrial enzyme 25-hydroxyvitamin D-1 $\alpha$-hydroxylase (CYP27B1) to generate the systemically circulating active form, 1,25-dihydroxyvitamin $\mathrm{D}\left[1,25(\mathrm{OH})_{2} \mathrm{D}\right][7,15-17]$. The renal synthesis of $1,25(\mathrm{OH})_{2} \mathrm{D}$ is regulated by several factors including serum phosphorus, calcium, fibroblast growth factor 23 (FGF-23), parathormone (PTH) and itself [7]. CYP27B1 is also expressed extrarenally in a multitude of tissues [17,43], including bone, placenta, prostate, keratinocytes, macrophages, T-lymphocytes, dendritic cells, several cancer cells [44], and the parathyroid gland [45] and enables the production of $1,25(\mathrm{OH})_{2} \mathrm{D}$. This active form of vitamin $\mathrm{D}$ is locally active and exerts auto- or paracrine effects [15,17].

$1,25(\mathrm{OH})_{2} \mathrm{D}$ induces its own destruction by rapidly inducing the 25-hydroxyvitamin $\mathrm{D}$-24-hydroxylase (CYP24A1), which leads to the multistep catabolism of both $25(\mathrm{OH}) \mathrm{D}$ and $1,25(\mathrm{OH})_{2} \mathrm{D}$ into biologically inactive, water-soluble metabolites including calcitroic acid [7,18] (Figure 1).

\section{Vitamin D Receptor (VDR)—Distribution and Function}

$1,25(\mathrm{OH})_{2} \mathrm{D}$, either produced in the kidneys [7] or extrarenally in the target tissues [15,17], is the ligand of the vitamin D receptor (VDR) whose widespread distribution across many tissues explains the myriad of physiological actions of vitamin D. By interacting with the VDR, a transcription factor $[17,46], 1,25(\mathrm{OH})_{2} \mathrm{D}$ regulates directly and indirectly the expression of up to 2000 genes [6,7], many of whose promoters contain specific vitamin D response elements (VDRE). The VDR partners with other transcription factors, most importantly the retinoid X receptor (RXR) [47], and coactivators and corepressors provide target gene specificity [48-50]. A membrane-bound VDR may also exist and mediate more immediate, non-genomic actions of $1,25(\mathrm{OH})_{2} \mathrm{D}[44,51,52]$.

\section{Prevalence of Vitamin D Deficiency and Insufficiency}

$25(\mathrm{OH}) \mathrm{D}$ is the vitamin D metabolite that is measured to assess a patient's vitamin D status [7,17]. Vitamin D deficiency is diagnosed when $25(\mathrm{OH}) \mathrm{D}<20 \mathrm{ng} / \mathrm{mL}[16,53]$, vitamin $\mathrm{D}$ insufficiency is 
defined as $25(\mathrm{OH}) \mathrm{D}$ of $21-29 \mathrm{ng} / \mathrm{mL}$, and $25(\mathrm{OH}) \mathrm{D}>30 \mathrm{ng} / \mathrm{mL}$ is considered sufficient, with 40-60 ng/mL being the preferred range [16]. Vitamin D intoxication usually doesn't occur until $25(\mathrm{OH}) \mathrm{D}>150 \mathrm{ng} / \mathrm{mL}[7,16,23]$.

These reference values are in part based on the finding, that the decline of parathyroid hormone $(\mathrm{PTH})$ concentrations with increasing $25(\mathrm{OH}) \mathrm{D}$ levels in adults reached its nadir asymptotically at a $25(\mathrm{OH}) \mathrm{D}$ of $\sim 30-40 \mathrm{ng} / \mathrm{mL}$ in several studies [7,16,23,54-56]. However, a recent cross-sectional analysis of more than 300,000 paired serum PTH and 25(OH)D levels revealed no threshold, even at 25(OH)D levels $>60 \mathrm{ng} / \mathrm{mL}$, above which a further increase of the $25(\mathrm{OH}) \mathrm{D}$ level failed to further suppress PTH levels. The analysis also showed a strong age-dependency of the PTH-25(OH)D relationship [57].

According to studies in Canada, 30\%-50\% of children and adults are vitamin D deficient [58-60]. The National Health and Nutrition Examination Surveys 2001-2006 showed a prevalence of vitamin D deficiency of $33 \%$ [60,61]. Studies in Indian school children revealed a prevalence of severe vitamin D deficiency $(<9 \mathrm{ng} / \mathrm{mL})$ in more than $35 \%$ [62] and over $80 \%$ of pregnant women in India had 25(OH)D levels $<22.5 \mathrm{ng} / \mathrm{mL}$ [63]. Also reports from Africa [64], Australia [65], Brazil [66], Middle East [67,68], Mongolia [69], and New Zealand [70] documented a high risk for vitamin D deficiency in both adults and children $[60,71]$.

Based on these findings, it has been estimated that 1 billion people worldwide are vitamin $\mathrm{D}$ deficient or insufficient [7,60] (Figure 3A-C).

Figure 3. (A) Prevalence at risk of vitamin D deficiency defined as a 25-hydroxyvitamin D $<12-20 \mathrm{ng} / \mathrm{mL}$ by age and sex: United States, 2001-2006. (B) Mean intake of vitamin D (IU) from food and food plus dietary supplements from Continuing Survey of Food Intakes by Individuals (CSFII) 1994-1996, 1998 and the Third National Health and Nutrition Examination Survey (NHANES III) 1988-1994. (C) Reported incidence of vitamin D deficiency defined as a 25-hydroxyvitamin $\mathrm{D}<20 \mathrm{ng} / \mathrm{mL}$ around the globe including Australia (AU), Canada (CA), China (CH), India (IN), Korea (KR), Malaysia (MA), Middle East (ME), Mongolia (MO), New Zealand (NZ), North Africa (NA), Northern Europe (NE), United States (USA) [60]. Note: This figure is reproduced with permission from [60], Copyright (C) 2012 The Endocrine Society.

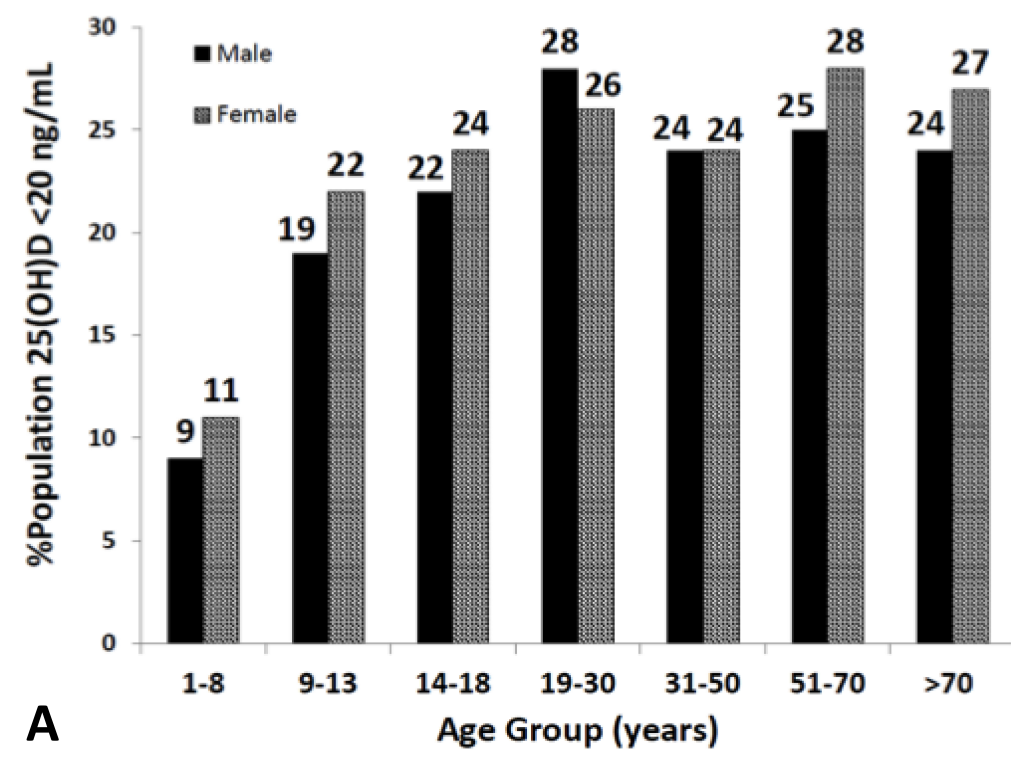


Figure 3. Cont.
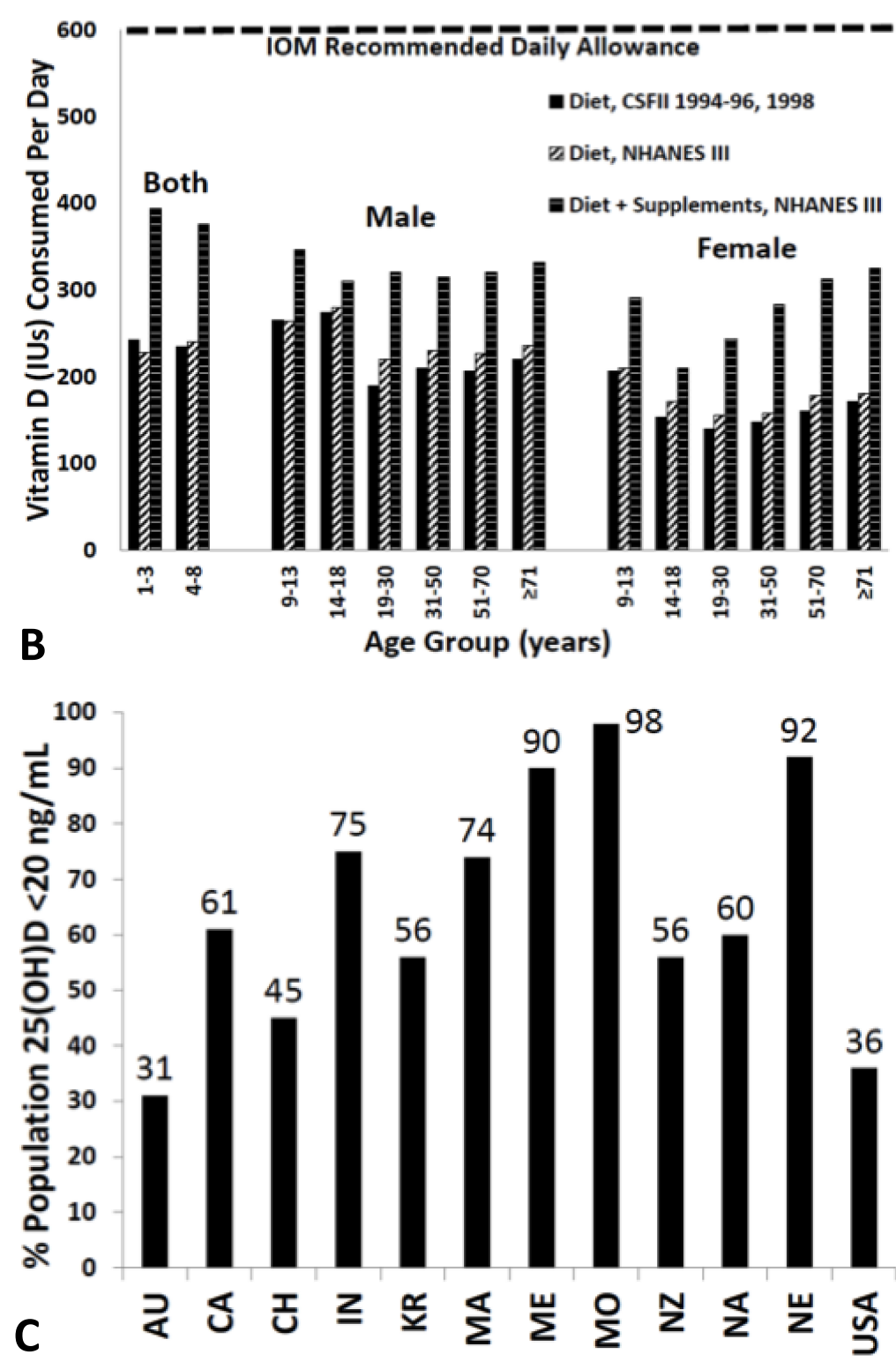

\section{Vitamin D and Calcium and Phosphorus Metabolism}

Vitamin D plays an important role in the calcium and phosphorus metabolism and helps ensure adequate levels of these minerals for metabolic functions and bone mineralization [7]. 1,25(OH $)_{2} \mathrm{D}$ increases the efficiency of intestinal calcium absorption from $10 \%-15 \%$ to $30 \%-40 \%$ by interacting with the VDR-RXR and thereby promoting the expression of an epithelial calcium channel and a calcium-binding protein [7,19,20]. Based on several experiments conducted in rodents $[72,73]$ it has been estimated that $1,25(\mathrm{OH})_{2} \mathrm{D}$ also increases the intestinal phosphorus absorption from $50 \%-60 \%$ to approximately $80 \%[7,14]$.

Vitamin D also mediates indirect effects on calcium and phosphorus by regulating the PTH levels. The parathyroid glands have CYP27B1 activity and the local production of $1,25(\mathrm{OH})_{2} \mathrm{D}$ using 25(OH)D as substrate could inhibit the synthesis of PTH [74]. However, 25(OH)D could also directly suppress PTH synthesis by directly activating the VDR [75]. Vitamin D deficiency is associated with 
lower levels of serum-ionized calcium, a stimulus leading to increased PTH levels. Conversely, higher calcium levels that are associated with higher 25(OH)D levels, suppress the PTH secretion. PTH increases tubular calcium and decreases renal phosphorus reabsorption [14] (Figure 1). PTH also stimulates the production of $1,25(\mathrm{OH})_{2} \mathrm{D}$ with the above mentioned effects on calcium and phosphorus homeostasis [7,14]. Moreover, both $\mathrm{PTH}$ and $1,25(\mathrm{OH})_{2} \mathrm{D}$ stimulate osteoblasts to mobilize skeletal calcium stores [7,17] (Figure 1). Vitamin D deficiency leads to secondary hyperparathyroidism with PTH-enhanced $1,25(\mathrm{OH})_{2} \mathrm{D}$ production and is often associated with normal to high $1,25(\mathrm{OH})_{2} \mathrm{D}$ levels [7].

\section{Bone Health}

In the mid-1600s most children living in the crowded and polluted industrialized cities in Northern Europe developed a severe bone-deforming disease, rickets, that was characterized by growth retardation, enlargement of the epiphyses of the long bones, deformities of the legs, bending of the spine, knobby projections of the ribcage, and weak and toneless muscles [14,76] (Figure 4). Autopsy studies in children in the Netherlands and Boston in the early 1900s showed a rickets prevalence of $80 \%-90 \%$ [14]. In the 19th and 20th century, the major discoveries regarding the pathogenesis and prevention of rickets were made. In 1822, the importance of sun exposure for the prevention and cure of rickets was recognized by Sniadecki [77]. In 1890, these observations were extended and the recommendation of sun baths to prevent rickets was promoted by Palm [78]. In 1919, Huldschinski $[79,80]$ found that exposing children to UV radiation from a sun quartz lamp (mercury arc lamp) or carbon arc lamp was effective in treating rickets. In 1918, Mellanby et al. [81] prevented rickets in puppies with cod liver oil. McCollum et al. [82] called this new nutritional factor vitamin D. Hess and Weinstock [83] and Steenbock and Black [84] observed that UV irradiation of various foods and oils imparted antirachitic activity [14].

Vitamin D sufficiency is pivotal for normal skeletal development both in utero [7,85] and in childhood [14], and for achieving and maintaining bone health in adults [23]. This is due to the fact that vitamin D sufficiency leads to an adequate calcium-phosphorus product $\left(\mathrm{Ca}^{2+} \times \mathrm{HPO}^{2-}\right)$ resulting in an effective bone mineralization [14]. Maternal vitamin D insufficiency during pregnancy was associated with a significant reduction in bone mineral acquisition in infants [85] that still persisted 9 years after birth [86]. In children whose epiphyseal plates haven't closed, vitamin D deficiency with $25(\mathrm{OH}) \mathrm{D}$ levels $<15 \mathrm{ng} / \mathrm{mL}$ causes chondrocyte disorganization and hypertrophy at the mineralization front as well as skeletal mineralization defects. This results in bone deformities and short stature, the typical signs of vitamin D deficiency rickets [14,87].

In adults low 25(OH)D and high PTH also lead to a low serum calcium $\times$ phosphorus product, resulting in osteomalacia, i.e., a defective mineralization of the collagen matrix causing a reduction of structural support and being associated with an increased risk of fracture [17,28]. Results from the National Health and Nutrition Examination Survey III (NHANES III) showed that bone density in the hip was directly related to the serum $25(\mathrm{OH}) \mathrm{D}$ level in both genders of all ethnicities $[88,89]$. A German study examined 25(OH)D serum levels and transiliac crest bone specimens of 675 individuals mainly in the 6th and 7th decade of life (401 males, mean age $58.7 \pm 17$ years, and 274 females, mean age: $68.3 \pm 17.3$ years) dying of unnatural death, such as a motor vehicle accident. 
The bone biopsies were taken within $48 \mathrm{~h}$ after death as well as the blood samples. Various previous experiments had shown that the $25(\mathrm{OH}) \mathrm{D}$ serum levels were stable for at least 10 days postmortem. While there's no uniformly accepted osteoid volume cut-off for the histologic diagnosis of osteomalacia, the study showed a prevalence of osteomalacia of over $25 \%$ when using a threshold of $>2 \%$ osteoid volume/bone volume $(\mathrm{OV} / \mathrm{BV})$ for the diagnosis of osteomalacia and a prevalence of $>43 \%$ when using a threshold of $1.2 \% \mathrm{OV} / \mathrm{BV}$ as described by Delling in 1975 [90]. Osteomalacia was absent in all individuals with $25(\mathrm{OH}) \mathrm{D}>30 \mathrm{ng} / \mathrm{mL}$, suggesting this as minimum serum level for maintenance of bone health. However, no minimum $25(\mathrm{OH}) \mathrm{D}$ level could be determined that was inevitably associated with mineralization defects [91].

One possible explanation is that obtaining a single blood level of $25(\mathrm{OH}) \mathrm{D}$ doesn't provide information about the long-term vitamin D status of the individual. It is possible that for example that the subject became ill during the winter and stopped ingesting foods containing vitamin D or decreased sun exposure during the summer that would acutely lower blood levels of $25(\mathrm{OH}) \mathrm{D}$ without causing osteomalacia.

Figure 4. Sister (right) and brother (left) ages 4 years and 6.5 years, respectively, demonstrating classic knock-knees and bow legs, growth retardation, and other skeletal deformities [14]. Note: This figure is reproduced with permission from [14], Copyright (C) 2006 American Society for Clinical Investigation.

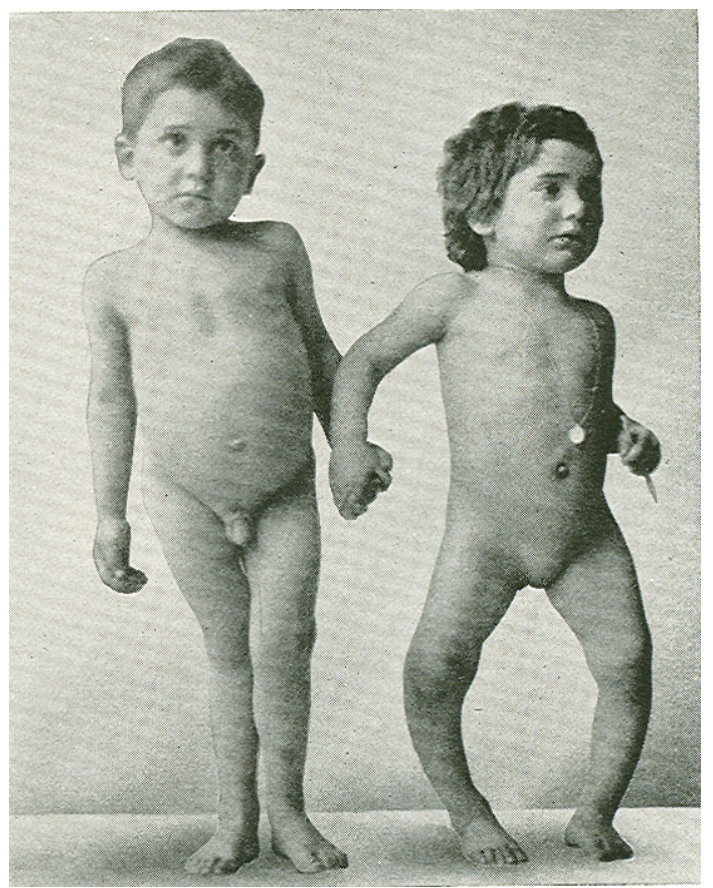

\section{Osteoporosis and Fractures}

As a decrease in 25(OH)D leads to secondary hyperparathyroidism associated with osteoclastogenesis and an increase in bone resorption exceeding osteoblast-mediated bone formation [88], this can precipitate and exacerbate osteopenia and osteoporosis in adults [17,92,93].

Osteoporosis has a prevalence of $\sim 1 / 3$ in women $60-70$ years of age and of $\sim 2 / 3$ in women 80 years of age or older [7]. It's estimated that currently 10 million Americans have osteoporosis with 
1.5 to 2 million osteoporosis-related fractures annually [94]. An osteoporosis-related fracture will be experienced by one in eight men over age 50 years in their lifetime [95].

Vitamin D promotes bone health by maintaining the PTH levels in a physiologically healthy level, stimulating osteoblastic activity, and promoting bone mineralization as well as reducing risk of falls thereby reducing risk of fracture [93,96].

According to data from the Women's Health Initiative [97], the odds ratio of risk for hip fracture was inversely related to the serum $25(\mathrm{OH}) \mathrm{D}$ level [88]. There's evidence that patients with $25(\mathrm{OH}) \mathrm{D}$ levels $>30 \mathrm{ng} / \mathrm{mL}$ have a lower risk of fracture. Several studies have been conducted to evaluate the effect of vitamin D supplementation on the fracture risk, with some studies showing a significant reduction of the risk of fractures while others didn't [98]. One of these showed that the supplementation with calcium (1200 mg) and vitamin $\mathrm{D}_{3}$ (800 IU/day) decreased the number of hip fractures by $43 \%(p=0.043)$ and the total number of nonvertebral fractures by $32 \%$ [99]. The RECORD study however, did not show a reduction in fracture risk with supplementation with vitamin D (800 IU/day), or calcium (1000 mg/day), or both [100], but often compliance was poor and serum 25(OH)D levels were not measured at the end of the study in most participants $[7,98,100]$. A meta-analysis of more than 30,000 participants did show that supplementation with vitamin D ( $\geq 792 \mathrm{IU} /$ day) led to a significant reduction in the risk of fracture; the risk of hip fracture was reduced by $30 \%$, the risk of any non-vertebral fracture by $14 \%$ [98-106].

\section{Muscular Health and Falls}

Vitamin D exerts multiple effects on muscle health [107]. Its active form $1,25(\mathrm{OH})_{2} \mathrm{D}$ could be produced locally in muscle cells as suggested by the recent identification of CYP27B1 bioactivity in regenerating mouse muscle and skeletal muscle cells [108], however other studies have failed to detect this enzyme in muscle cells [109]. $1,25(\mathrm{OH})_{2} \mathrm{D}$ is thought to modulate muscle function via the VDR, which seems to be expressed in skeletal muscles [109-113], by regulating gene transcription and promoting de-novo protein synthesis [107]. Also, rapid non-genomic pathways involving a membrane-bound vitamin $\mathrm{D}$ receptor could exist and affect the calcium handling involving the sarcoplasmic reticulum and the calcium signaling in muscle cells [109]. Several studies indicate that the muscle function depends on the VDR genotype in the muscle cell [114,115]. The possibility of a direct interaction between $25(\mathrm{OH}) \mathrm{D}$ and the VDR has been proposed in CYP27B1 ${ }^{-1}$ cells $[109,116]$. However, the existence of a VDR in muscle cells is discussed highly controversially, as a more recent study failed to detect the VDR in muscle cells and as the antibodies used for immunocytochemical staining to detect the VDR in previous studies have been shown to be not exclusively specific for the VDR and could explain potentially false-positive results in these previous studies [117].

Vitamin D deficiency is associated with diffuse muscle pain, muscle weakness [7,118], predominantly in the proximal muscle groups [115], and a reduction in performance speed [107,119]. This is caused by muscle atrophy of mainly type II muscle fibers [115]. Proximal muscle weakness in severe vitamin D deficiency could also be caused by secondary hyperparathyroidism and resultant hypophosphatemia $[60,106,120]$.

There is a positive association between $25(\mathrm{OH}) \mathrm{D}$, lower extremity function, proximal muscle strength and physical performance [107,121,122]. Muscle strength [123] and postural and dynamic 
balance [124] were increased by vitamin D supplementation [107]. The effect of vitamin D supplementation on the risk of falls was examined in a randomized, controlled multi-dose study, showing that the supplementation of 800 IU/day lowered the adjusted-incidence rate ratio of falls by $72 \%$ compared to those taking placebo over 5 months [125]. A meta-analysis of 8 randomized controlled trials $(n=2426)$ showed that supplemental vitamin D of $700-1000 \mathrm{IU} /$ day or a serum $25(\mathrm{OH}) \mathrm{D}$ of $\geq 24 \mathrm{ng} / \mathrm{mL}$ reduced the risk of falls by $19 \%$ and $23 \%$ respectively. No benefit was observed with lower supplemental doses or lower serum 25(OH)D concentrations [126].

\section{Cancer}

Living at higher latitudes with lower UV exposure and thus lower vitamin D production is associated with an increased risk for the occurrence of a variety of cancers and with an increased likelihood of dying from them, as compared to living at lower latitudes [7,17,127,128]. A recent review of ecological studies associating solar UVB exposure-vitamin D and cancers found strong inverse correlations with solar UVB irradiance for 15 types of cancer: bladder, breast, cervical, colon, endometrial, esophageal, gastric, lung, ovarian, pancreatic, rectal, renal, and vulvar cancer; and Hodgkin's and non-Hodgkin's lymphoma [129].

An inverse association between $25(\mathrm{OH}) \mathrm{D}$ and the incidence of several cancers and mortality from these cancers has been shown in case-control studies, prospective and retrospective studies [130-140], especially for cancers of the colon, breast and prostate [7]. Regarding colon cancer, the Nurses' Health cohort study $(n=32,826)$ showed an inverse association of the odds ratios for colorectal cancer with the median $25(\mathrm{OH}) \mathrm{D}$ serum levels. At $16.2 \mathrm{ng} / \mathrm{mL}$ the odds ratio was 1 and 0.53 at $39.9 \mathrm{ng} / \mathrm{mL}$ $(p \leq 0.01)[7,140]$.

These associational studies have certain limitations regarding the establishment of a causality between vitamin D status and a reduced risk of cancer, e.g., as low serum 25(OH)D levels are also linked with confounding factors related to higher cancer risk, including obesity (vitamin D is sequestered in adipose tissue), and lack of physical activity (correlated with less time outdoors and less solar exposure) [138]. However, a population-based, double-blind, randomized placebo-controlled trial of 4 years duration with more than thousand postmenopausal women, whose principal secondary outcome was cancer incidence, showed that the supplementation with calcium (1400-1500 mg/day) and vitamin $\mathrm{D}_{3}(1100 \mathrm{IU} /$ day) reduced the relative risk $(\mathrm{RR})$ of cancer by $\sim 60 \%(p<0.01)$. The repetition of a cancer free survival analysis after the first 12 months revealed, that the relative risk for the calcium + vitamin D group was reduced by $\sim 77 \%$ (confidence interval [CI]: $0.09-0.60 ; p<0.005$ ). Multiple regression models also showed that both treatment and serum 25(OH)D concentrations were significant, independent predictors of cancer risk [137].

Mounting evidence suggests a biological plausibility for anti-carcinogenic effects of vitamin D, which could explain these results. $1,25(\mathrm{OH})_{2} \mathrm{D}$, which has been shown to be produced locally by various cancer cells metabolizing the substrate 25(OH)D [38], inhibits carcinogenesis by several mechanisms [141]. 1,25(OH $)_{2} \mathrm{D}$ exerts anti-proliferative effects on cancer cells by promoting cyclin-dependent kinase (CDK) inhibitor synthesis, and by influencing several growth factors and their signaling pathways including insulin-like growth factor 1 (IGF-1), transforming growth factor $\beta$ (TGF $\beta$ ), Wnt/ $\beta$-catenin, MAP kinase 5 (MAPK5) and nuclear factor $\kappa B$ (NF-kB) [142] (Figure 5). 
Figure 5. Metabolism of 25-hydroxyvitamin $\mathrm{D}[25(\mathrm{OH}) \mathrm{D}]$ to 1,25 dihydroxyvitamin $\mathrm{D}$ $1,25(\mathrm{OH})_{2} \mathrm{D}$ for non-skeletal functions. When a monocyte/macrophage is stimulated through its toll-like receptor 2/1 (TLR2/1) by an infective agent such as Mycobacterium tuberculosis (TB), or its lipopolysaccharide (LPS) the signal upregulates the expression of vitamin D receptor (VDR) and the 25-hydroxyvitamin D-1-hydroxylase (1-OHase). $25(\mathrm{OH}) \mathrm{D}$ levels $>30 \mathrm{ng} / \mathrm{mL}$ provides adequate substrate for the 1-OHase to convert it to $1,25(\mathrm{OH})_{2} \mathrm{D} .1,25(\mathrm{OH})_{2} \mathrm{D}$ returns to the nucleus where it increases the expression of cathelicidin which is a peptide capable of promoting innate immunity and inducing the destruction of infective agents such as TB. It is also likely that the $1,25(\mathrm{OH})_{2} \mathrm{D}$ produced in the monocytes/macrophage is released to act locally on activated T (AT) and activated $\mathrm{B}(\mathrm{AB})$ lymphocytes which regulate cytokine and immunoglobulin synthesis respectively [143-147]. When $25(\mathrm{OH}) \mathrm{D}$ levels are $\sim 30 \mathrm{ng} / \mathrm{mL}$, it reduces risk of many common cancers [130-140]. It is believed that the local production of $1,25(\mathrm{OH})_{2} \mathrm{D}$ in the breast, colon, prostate, and other cells regulates a variety of genes that control proliferation. Once $1,25(\mathrm{OH})_{2} \mathrm{D}$ completes the task of maintaining normal cellular proliferation and differentiation, it induces the 25-hydroxyvitamin D-24-hydroxylase (24-OHase). The 24-OHase enhances the metabolism of $1,25(\mathrm{OH})_{2} \mathrm{D}$ to calcitroic acid which is biologically inert [7,18]. Thus, the local production of $1,25(\mathrm{OH})_{2} \mathrm{D}$ does not enter the circulation and has no influence on calcium metabolism. The parathyroid glands have 1-OHase activity [45] and the local production of $1,25(\mathrm{OH})_{2} \mathrm{D}$ inhibits the expression and synthesis of PTH [74]. The production of $1,25(\mathrm{OH})_{2} \mathrm{D}$ in the kidney enters the circulation and is able to downregulate renin production in the kidney [148,149] and to stimulate insulin secretion in the $\beta$-islet cells of the pancreas $[148,150]$. Note: This figure is reproduced with permission from [21], Copyright (C) 2007 Michael F. Holick.

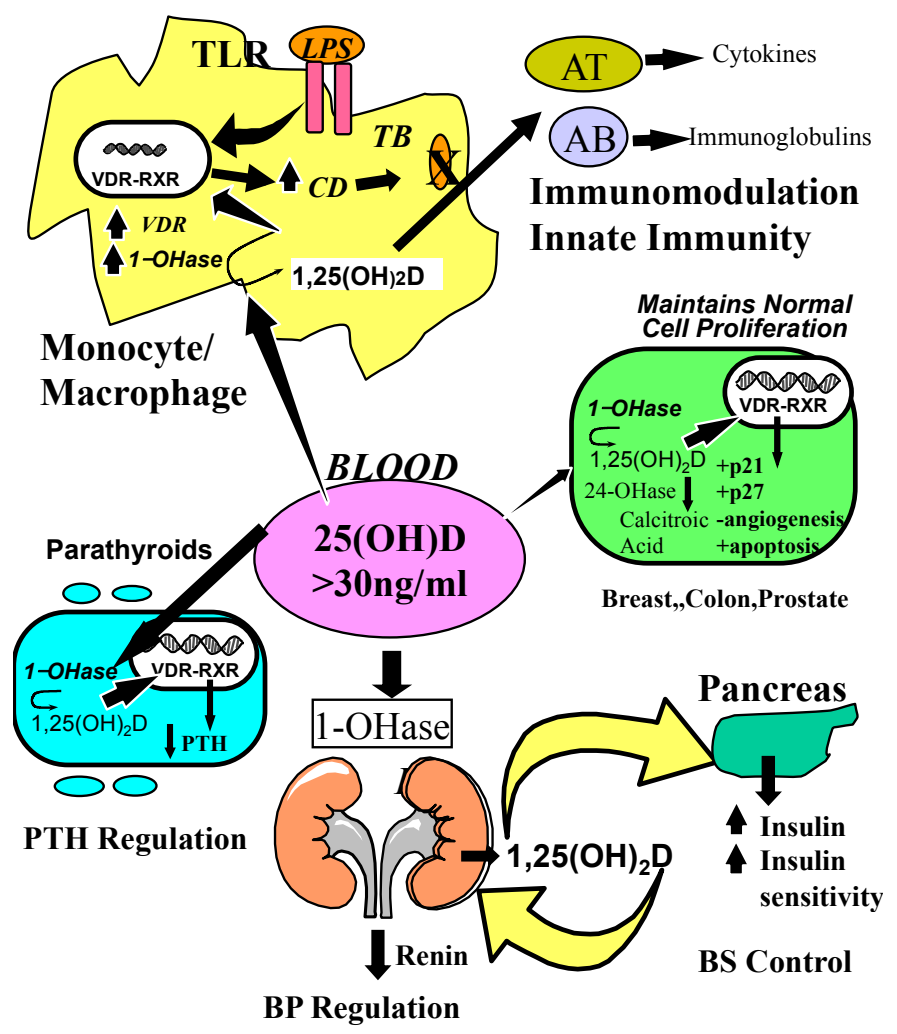


Apoptosis is characterized as programmed cell death permitting the removal of damaged cells including cancer cells in multicellular organisms without impairing the cellular microenvironment. Defective apoptosis plays a major role in the development and progression of cancer [151]. It has been shown, that both immunobiological mechanisms of cancer immunosurveillance and cancer immunoediting [152], as well as chemotherapeutic agents and radiation, utilize the apoptotic pathway to induce cancer cell death $[151,153] .1,25(\mathrm{OH})_{2} \mathrm{D}_{3}$ might exert anti-carcinogenic effects by promoting various pro-apoptotic mechanisms including the downregulation of the anti-apoptotic gene Bcl-2 [154] and by upregulating of the pro-apoptotic gene $\mathrm{Bax}$ [155], 1,25(OH) $)_{2} \mathrm{D}_{3}$ induces differentiation, partly by reducing the expression of the $c-m y c$ oncogene $[141,156]$. It regulates the prostaglandin (PG) metabolism and signaling, thus decreasing PG-mediated promotion of carcinogenesis [141,157]. It suppresses tumor angiogenesis, e.g., mediated by $1,25(\mathrm{OH})_{2} \mathrm{D}$ 's effects on the PG synthesis and by regulating the expression of crucial factors controlling the angiogenesis. $1,25(\mathrm{OH})_{2} \mathrm{D}_{3}$ suppresses tumor invasion and metastasis by various mechanisms [141], e.g., by decreasing the expression and activity of cell invasion-associated serine proteases and metalloproteinases and inducing their inhibitors [158], and by inducing E-cadherin expression, contributing to adhesive properties of cells $[141,159]$. Other effects mediated by $1,25(\mathrm{OH})_{2} \mathrm{D}$ are thought to be the induction of autophagy as process to trigger the death of cancer cells and to block tumor growth and by inducing enzymes involved in antioxidant defense mechanisms and DNA-repair [142]. $1,25(\mathrm{OH})_{2} \mathrm{D}$ also regulates androgen and estrogen receptor signaling, thereby inhibiting tumor growth of some sex hormone-dependent tumors such as prostate and breast cancer. It has also been shown to reduce the expression of aromatase, thereby inhibiting breast cancer growth [141].

\section{Vitamin D and Cardiovascular Risk}

Most epidemiological and prospective studies as well as meta-analyses [148,160-163] suggest a significant inverse association between $25(\mathrm{OH}) \mathrm{D}$ serum levels and cardiovascular risk. The prospective Intermountain Heart Collaborative Study with more than 40,000 participants revealed that $25(\mathrm{OH}) \mathrm{D}$ $<15 \mathrm{ng} / \mathrm{mL}$ compared to $25(\mathrm{OH}) \mathrm{D}>30 \mathrm{ng} / \mathrm{mL}$ was associated with highly significant increases in the prevalence of type 2 diabetes mellitus, hypertension, hyperlipidemia, and peripheral vascular disease, coronary artery disease, myocardial infarction, heart failure, and stroke $(p<0.0001)$, as well as with incident death (all-cause mortality was used as primary survival measure), heart failure, coronary artery disease/myocardial infarction $(p<0.0001)$, stroke $(p=0.003)$, and their composite $(p<0.0001)$ [164].

A meta-analysis examining the association between vitamin D status and the risk of cerebrovascular events including $>1200$ stroke cases found that the pooled relative risk for stroke was $52 \%$ higher when comparing $25(\mathrm{OH}) \mathrm{D}$ levels $\leq 12.4 \mathrm{ng} / \mathrm{mL}$ with $25(\mathrm{OH}) \mathrm{D}$ levels $>18.8 \mathrm{ng} / \mathrm{mL}$ [165].

Many of these associations are well established, causation however is yet to be proven [166]. Individuals spending less time exercising outdoors in the sun, e.g., have a higher risk of developing cardiovascular diseases, and those individuals also will likely have lower 25(OH)D levels coincidentally [166,167]. Also, obesity, a condition associated with cardiovascular disease [168], is associated with a lower vitamin D status due to a sequestration and volumetric dilution of the lipophilic vitamin $\mathrm{D}$ in the fat tissue $[23,166,169,170]$, potentially explaining the described correlations [166]. Despite these limitations many studies suggest a biological plausibility for the beneficial effects of vitamin D on cardiovascular risk factors and cardiovascular health. 
The vitamin $\mathrm{D}$ receptor is present in endothelium, vascular smooth muscle, and cardiomyocytes $[162,166]$ and may protect against atherosclerosis through the inhibition of macrophage cholesterol uptake and foam cell formation, reduced vascular smooth muscle cell proliferation, and reduced expression of adhesion molecules in endothelial cells [166] and through inhibition of cytokine release from lymphocytes [162]. Several meta-analyses indicate an inverse association between vitamin D status and hypertension [171]. Studies showed, that antihypertensive effects were associated with raising 25(OH)D levels with vitamin D supplementation [172-174] or UVB exposure [175].

Mechanistically, this effect could be partly mediated by vitamin D's capability to suppress the levels of PTH, which can cause arrhythmias and lead to myocardial hypertrophy and increased blood pressure $[148,176]$. $1,25(\mathrm{OH})_{2} \mathrm{D}_{3}$ has also been shown to suppress the levels of renin and could contribute to vitamin D's potential antihypertensive properties [148,149].

A meta-analysis examining the association between vitamin $\mathrm{D}$ status or vitamin $\mathrm{D}$ supplementation, and incident type 2 diabetes showed that individuals with $25(\mathrm{OH}) \mathrm{D}$ levels $>25 \mathrm{ng} / \mathrm{mL}$ compared to those with $25(\mathrm{OH}) \mathrm{D}<14 \mathrm{ng} / \mathrm{mL}$ had a $43 \%$ lower risk of developing type 2 diabetes and that a vitamin D supplementation with $>500 \mathrm{IU} /$ day compared to $<200 \mathrm{IU} /$ day reduced the risk by $13 \%$ [177]. In the Nurses' Health Study $>83,000$ women were followed-up prospectively and it was shown, that a combined daily intake of $>1200 \mathrm{mg}$ calcium and $>800$ IU vitamin D was associated with a 33\% lower risk of type 2 diabetes with RR of 0.67 (CI: 0.49-0.90) compared with an intake of $<600 \mathrm{mg}$ calcium and $400 \mathrm{IU}$ vitamin D [178]. A prospective study following-up more than 2000 participants showed, that the risk of progression from prediabetes to diabetes was reduced by $62 \%$ when comparing the highest quartile of $25(\mathrm{OH}) \mathrm{D}$ levels with the lowest quartile $[179,180]$.

This could be explained by experimental findings indicating that vitamin $\mathrm{D}$ exerts various antidiabetic effects. The VDR is expressed in pancreatic beta cells and $1,25(\mathrm{OH})_{2} \mathrm{D}$ stimulates insulin secretion [148,150]. Improvement in vitamin D status also leads to a improvement of insulin sensitivity, mediated for example by upregulation of insulin receptors [148], and modulates inflammation, which is also thought to play a role in type 2 diabetes [150,179] (Figure 5).

\section{Vitamin D's Role in Autoimmune Disease}

Ecological studies have shown that the prevalence of certain autoimmune diseases was associated with latitude, suggesting a potential role of sunlight exposure, and thus vitamin $\mathrm{D}$ production, on the pathogenesis of type 1 diabetes mellitus, multiple sclerosis and Crohn's disease [181]. The increased prevalence at higher latitudes has been shown for multiple sclerosis (MS) [181,182], inflammatory bowel disease [183], rheumatoid arthritis [184] and type 1 diabetes [181,182,185].

A few case-control studies relate the vitamin D status to the risk of developing these autoimmune diseases [181]. One of them, a prospective, nested case-control study analyzed serum samples and the data of disability databases of more than seven million US military personnel, and showed, that among whites (148 cases, 296 controls), the risk of multiple sclerosis significantly decreased with increasing levels of $25(\mathrm{OH}) \mathrm{D}$ (odds ratio for a $20 \mathrm{ng} / \mathrm{mL}$ increase in $25(\mathrm{OH}) \mathrm{D}$ was 0.59 (95\% CI: $0.36-0.97$ ). When comparing the highest quintile of $25(\mathrm{OH}) \mathrm{D}$ with the lowest, the odds ratio for developing MS was 0.38 (95\% CI: $0.19-0.75 ; p=0.006)$, with an particularly strong inverse association for $25(\mathrm{OH}) \mathrm{D}$ levels measured before age 20 years [186]. 
A study addressing vitamin D's effect on multiple sclerosis showed the safety of high-dose vitamin D ( 14,000 IU/day). It appeared to have immunomodulatory effects including a persistent reduction in T-cell proliferation and resulted in a trend for fewer relapse events [187]. When examining the association between 25(OH)D serum levels and the relapse rate in MS patients before and after supplementation with $\sim 3000$ IU vitamin D per day, a significant strong inverse relationship between the relapse incidence rate and the $25(\mathrm{OH}) \mathrm{D}$ level $(p<0.0001)$ was found [188].

An inverse association between maternal 25(OH)D levels and the risk for type 1 diabetes in the offspring has been shown in a population-based, nested cohort study of $\sim 30,000$ pregnant women. Compared to the upper quartile of $25(\mathrm{OH}) \mathrm{D}$ levels, the odds of type 1 diabetes in the women with the lowest quartile was more than twofold higher [189]. A birth-cohort study with $>10,000$ children showed, that regular supplementation with 2000 IU vitamin D per day in the first year of life was associated with a $88 \%$ reduction of the risk for type 1 diabetes later in life when compared to those without supplementation [190]. However, another study did not show a statistically significant association between taking cod liver oil or other vitamin D supplements in the first year of life and the risk of type 1 diabetes mellitus [191].

Merlino et al. [192] showed in a prospective cohort study of 29,368 women of ages 55-69 years without a history of rheumatoid arthritis at study baseline, that greater intake (highest versus lowest tertile) of vitamin D was inversely associated with risk of rheumatoid arthritis (RR 0.67 ; 95\% CI: $0.44-1.00 ; p$ for trend $=0.05$ ).

These associations indicate a contributory role of vitamin D in the pathophysiology of autoimmune diseases. This is further supported by various experimental findings showing vitamin D's capability to regulate chemokine production, counteracting autoimmune inflammation and to induce differentiation of immune cells in a way that promotes self-tolerance. This involves the enhancement of the innate and the inhibition of the adaptive immune system by regulating the interactions between lymphocytes and antigen presenting cells. By increasing the quantity of Th2 lymphocytes and by inducing proliferation of dendritic cells with tolerance properties, vitamin D exerts anti-inflammatory and immunoregulatory effects [181].

Immune cells possess both the enzymatic machinery to produce $1,25(\mathrm{OH})_{2} \mathrm{D}$ and a VDR. This could explain, why certain polymorphisms in the VDR gene seem to affect the risk for multiple autoimmune diseases, the time of onset of disease and disease activity [181,193-197].

\section{Vitamin D and Infectious Diseases}

The plethora of effects of vitamin $\mathrm{D}$ on regulating the immune system plays a role in fighting infectious diseases [198]. Vitamin D enhances the innate immunity against various infections [143], especially tuberculosis, influenza and viral upper respiratory tract infections [198].

Historically, cod liver oil (one of only a few natural sources of vitamin D) was given to tuberculosis patients in 19th and 20th century [199-201]. Later in the nineteenth century, tuberculosis patients were treated in sanatoriums with heliotherapy, i.e., sun exposure. In 1903, Niels Ryberg Finsen was awarded the Nobel prize for medicine "in recognition of his contribution to the treatment of diseases, especially lupus vulgaris (tuberculosis of the skin), with concentrated light radiation, whereby he has opened a new avenue for medical science" [199,202]. After vitamin D had been identified as the active 
ingredient in cod-liver oil [199,203], vitamin $\mathrm{D}_{2}$ was used successfully in the treatment of lupus vulgaris in several studies. In 1946 a report in Proc. R. Soc. Med. [204] stated that there was no room for doubt that calciferol (vitamin D) in adequate dosage will cure a substantial proportion of cases of lupus vulgaris [199,204]. In 1947 the first reference to successful treatment of pulmonary tuberculosis with vitamin D was published [199,205]. In the wake of the antibiotic era both heliotherapy and vitamin D therapy for treating tuberculosis patients were quickly forgotten [199,206]. However recent studies have suggested that vitamin D may have an important role to play in reducing risk for acquiring one of the most common and deadly infectious diseases that plague third world countries [206].

One case-control study examining the association between vitamin D status and tuberculosis showed, that the mean $25(\mathrm{OH}) \mathrm{D}$ levels were statistically significant different $(p<0.005)$ between patients with pulmonary and extrapulmonary tuberculosis $(10.7 \mathrm{ng} / \mathrm{mL})$ and controls $(19.5 \mathrm{ng} / \mathrm{mL})$ [207]. In another study, 25(OH)D levels $<10 \mathrm{ng} / \mathrm{mL}$ were significantly associated with active tuberculosis (OR 2.9; 95\% Cl: 1.3-6.5; $p=0.008$ ) [208]. A meta-analysis showed, that low serum 25(OH)D levels were associated with higher risk of active tuberculosis, and that the pooled effect size in random effects meta-analysis was 0.68 (95\% CI: 0.43-0.93), representing a medium to large effect [209]. A double-blind, placebo-controlled study in Mongolian school children $(n=120)$ examining the effect of vitamin D supplementation (800 IU/day) on tuberculin skin test conversion to positive showed a trend towards fewer conversions in the vitamin D group $(p=0.06)$, suggesting a potential role of vitamin D in reducing the rate of acquisition of latent tuberculosis infection [210].

Several interventional studies examining the effect of vitamin D supplementation in patients with active tuberculosis have been conducted. Some of them showed an improved immunity against mycobacteria [211], a significantly improved sputum conversion rate and a higher rate of radiological improvement [212], and a significantly hastened sputum culture conversion in participants with the tt genotype of the TaqI vitamin D receptor polymorphism [213]. There was also a higher rate of tuberculosis symptom improvement and a significantly higher weight gain $(p<0.005)$ in children [214]. A prospective, randomized placebo-controlled trial examining the effect of adjunctive vitamin D supplementation in patients receiving antimicrobial therapy showed that vitamin D supplementation led to an accelerated sputum smear conversion and an accelerated resolution of inflammation [215]. Another study however in which three doses of 100,000 IU vitamin $\mathrm{D}_{3}$ each were given during 8 months did not lead to a reduction in the clinical severity score or mortality [216].

Some studies examined the effect of vitamin D supplementation on the risk of influenza [217,218].

In 1981, R. Edgar Hope-Simpson proposed that a "seasonal stimulus" was intimately associated with solar radiation and explained the remarkable seasonality of epidemic influenza [219,220]. As the vitamin D status changes during the seasons, it has been suggested, that vitamin D could be this "seasonal stimulus" [219]. A randomized trial of vitamin $\mathrm{D}_{3}$ supplementation (1200 IU/day) in school children $(n=334)$ showed a significantly reduced risk for influence A as determined by both antibody and sputum testing compared to the placebo group (RR 0.58 ; 95\% CI: $0.34-0.99 ; p=0.04$ ) [218].

One study using questionnaires to retrospectively determine the occurrence of influenza-like disease in participants of 10 different clinical trials $(n=569)$, receiving 1111-6800 IU/day, however did not show a significant difference in the incidence and severity of influenza-like disease [217].

The NHANES III study $(n>18)$ revealed an inverse association between serum $25(\mathrm{OH}) \mathrm{D}$ levels and recent upper respiratory tract infections (URTI). Lower $25(\mathrm{OH}) \mathrm{D}$ levels were independently 
associated with recent URTI compared with $25(\mathrm{OH}) \mathrm{D}$ levels of $\geq 30 \mathrm{ng} / \mathrm{mL}$ (OR 1.36; 95\% CI: 1.01-1.84 for $<10 \mathrm{ng} / \mathrm{mL}$ and OR 1.24 ; $95 \%$ CI: $1.07-1.43$ for 10 to $<30 \mathrm{ng} / \mathrm{mL}$ ). In individuals with asthma or chronic obstructive airway disease this association was stronger (OR of 5.67 in asthma respectively OR of 2.26 in chronic obstructive airway disease) [221]. A study in Finish men $(n=800)$ found a significant association between $25(\mathrm{OH}) \mathrm{D}$ serum levels $<16 \mathrm{ng} / \mathrm{mL}$ and significantly more days of absence from duty due to respiratory infections $(p=0.004)$ [222]. In Indian children $(n=150)$ vitamin $\mathrm{D}$ deficiency has been associated with a significantly higher risk of acute lower respiratory infections [223].

A study with $>200$ participants whose primary endpoint was the effect of vitamin D supplementation on bone loss also revealed, that the vitamin $\mathrm{D}_{3}$ supplementation for 2 years with $800 \mathrm{IU} /$ day and for 1 year with $2000 \mathrm{IU} /$ day was associated with a significantly reduced risk of cold and influenza symptoms, an effect that was magnified with the supplementation of 2000 IU/day [198,224]. Other studies however did not show a statistically significant difference, possibly due to poor compliance $[225,226]$. Certain VDR polymorphisms were also associated with a significantly increased risk of acute lower respiratory tract infections [227].

Several mechanisms could explain vitamin D's potentially beneficial effects on infectious diseases. Monocytes and macrophages can sense pathogen-associated molecular patterns (PAMPs) of, e.g., tuberculosis by utilizing their toll-like receptors (TLRs). This induces both VDR and CYP27B1, which increases the local production of $1,25(\mathrm{OH})_{2} \mathrm{D}$ that is dependent on the serum $25(\mathrm{OH}) \mathrm{D}$ concentration $[145,228] .1,25(\mathrm{OH})_{2} \mathrm{D}$ enhances the innate immune system by inducing the production of antimicrobial peptides like cathelicidin, reactive oxygen species by the (reduced) nicotinamide adenine dinucleotide phosphate (NADPH) oxidase and potentially reactive nitrogen species by inducible nitric oxide synthase (iNOS), and by inducing autophagy [143-147] (Figure 4).

\section{Vitamin D and Respiratory Diseases}

Although some studies did not find a consistent association between 25(OH)D levels in cord blood, maternal vitamin D intake or status during pregnancy and the risk for asthma in childhood [229-236], in children with asthma, 25(OH)D levels seem to correlate positively with asthma control [237] and lung function [238], and inversely with corticosteroid use [239]. A few interventional studies examining vitamin D's effect on asthma exist [229]. One of them showed as secondary outcome that vitamin $\mathrm{D}_{3}$ supplementation (1200 IU/day) in school children was associated with a significant $83 \%$ reduced risk for asthma exacerbations [218]. Presumably vitamin D's immunmodulatory and pulmonary effects could play a role [229].

\section{Prevention and Treatment of Vitamin D Deficiency}

According to the Endocrine Society Practice Guidelines a screening for vitamin D deficiency by measuring the $25(\mathrm{OH}) \mathrm{D}$ serum level is only recommended for individuals at risk (the most important risk factors are listed in Figure 6), and not for the general population [16]. To prevent vitamin D deficiency, the Institute of Medicine (IOM) recommends, that infants should immediately receive a daily supplementation of vitamin D of 400 IUs during the first year of life. Individuals between 1 and 70 years should receive 600 IU of vitamin D daily and adults $>70$ years should receive a daily dose of 800 IU vitamin D [53] (Table 2). The serum 25(OH)D level increases for every 100 IU/day by 
$\sim 0.6-1.0 \mathrm{ng} / \mathrm{mL}[29,37,240,241]$. The doses recommended by IOM will likely increase the $25(\mathrm{OH}) \mathrm{D}$ level to $20 \mathrm{ng} / \mathrm{mL}$, which they considered to be adequate for bone health, but not to levels $>30 \mathrm{ng} / \mathrm{mL}$, as recommended by the Endocrine Society.

That's why the Endocrine Society recommended in its Practice Guidelines that infants during their first year of life receive a daily supplementation of 400-1000 IU (up to 2000 IU is safe), children and adolescents between 1 and 18 years a daily supplementation of 600-1000 IU (up to 4000 IU is safe), and adults $>18$ years a daily supplementation of 1500-2000 IU (up to 10,000 IU is safe) for the prevention of vitamin D deficiency [16,53] (Table 2).

Figure 6. A Schematic representation of the major causes for vitamin D deficiency and potential health consequences. Note: This figure is reproduced with permission from [21], Copyright (C) 2007 Michael F. Holick.

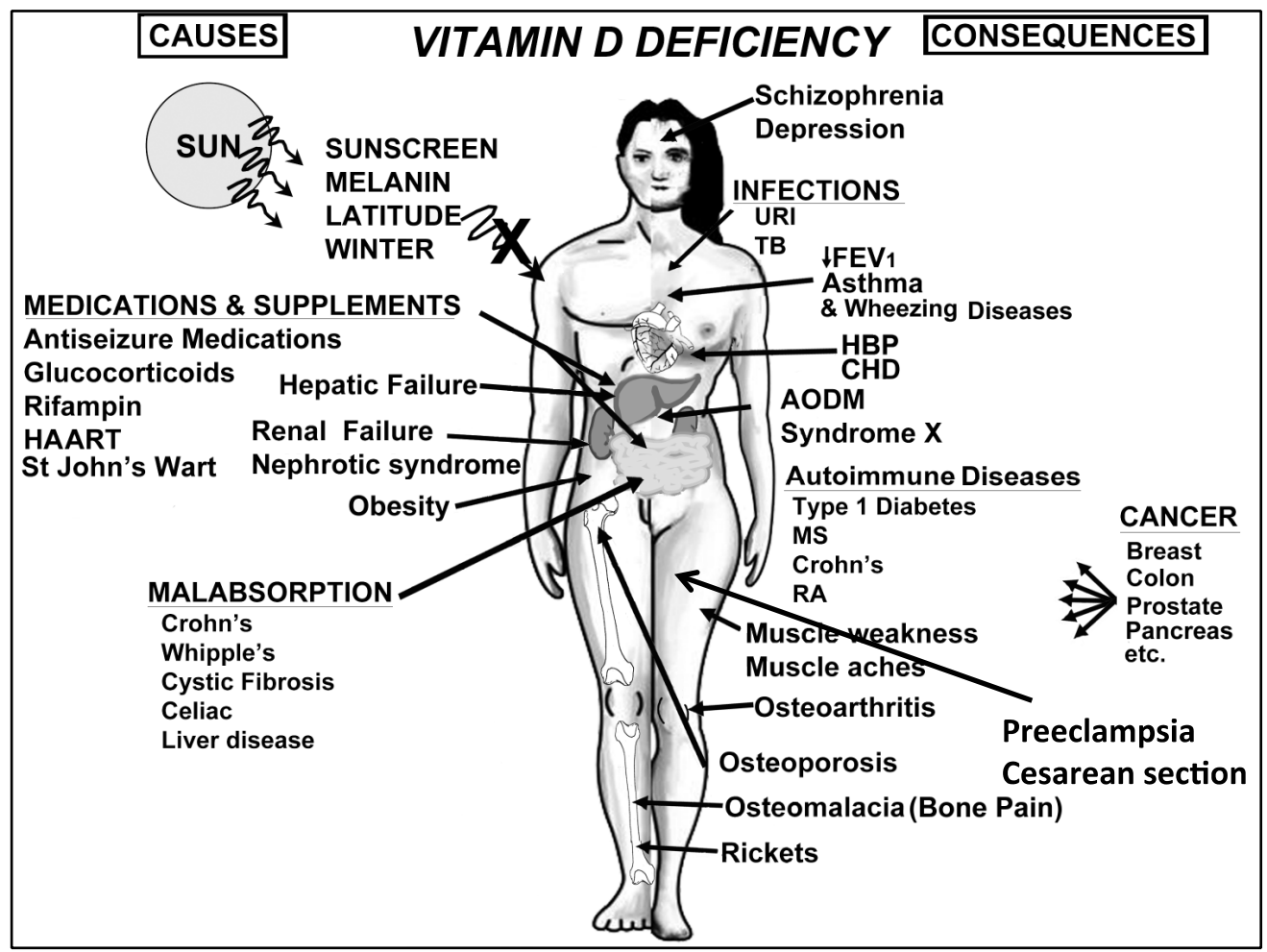

Table 2. Recommendations of the Institute of Medicine and the Endocrine Society Practice Guidelines for daily vitamin D supplementation to prevent vitamin D deficiency. This table is reproduced with permission from [16], Copyright (C) 2011 The Endocrine Society.

\begin{tabular}{|c|c|c|c|c|c|c|}
\hline \multirow[b]{2}{*}{$\begin{array}{l}\text { Life Stage } \\
\text { Group }\end{array}$} & \multicolumn{4}{|c|}{ IOM Recommendations } & \multicolumn{2}{|c|}{$\begin{array}{l}\text { Endocrine Society's } \\
\text { Recommendations }\end{array}$} \\
\hline & AI & EAR & RDA & $\mathbf{U L}$ & $\begin{array}{l}\text { Daily Allowance } \\
\text { (IU/day) }\end{array}$ & UL (IU) \\
\hline \multicolumn{7}{|l|}{ Infants } \\
\hline 0 to 6 months & $400 \mathrm{IU}(10 \mu \mathrm{g})$ & & & $1000 \mathrm{IU}(25 \mu \mathrm{g})$ & $400-1000$ & 2000 \\
\hline 6 to 12 months & $400 \mathrm{IU}(10 \mu \mathrm{g})$ & & & $1500 \mathrm{IU}(38 \mu \mathrm{g})$ & $400-1000$ & 2000 \\
\hline \multicolumn{7}{|l|}{ Children } \\
\hline $1-3$ years & & $400 \mathrm{IU}(10 \mu \mathrm{g})$ & $600 \mathrm{IU}(15 \mu \mathrm{g})$ & $2500 \mathrm{IU}(63 \mu \mathrm{g})$ & $600-1000$ & 4000 \\
\hline $4-8$ years & & $400 \mathrm{IU}(10 \mu \mathrm{g})$ & $600 \mathrm{IU}(15 \mu \mathrm{g})$ & $3000 \mathrm{IU}(75 \mu \mathrm{g})$ & $600-1000$ & 4000 \\
\hline
\end{tabular}


Table 2. Cont.

\begin{tabular}{|c|c|c|c|c|c|}
\hline \multicolumn{6}{|l|}{ Males } \\
\hline 9-13 years & $400 \mathrm{IU}(10 \mu \mathrm{g})$ & $600 \mathrm{IU}(15 \mu \mathrm{g})$ & $4000 \mathrm{IU}(100 \mu \mathrm{g})$ & $600-1000$ & 4000 \\
\hline $14-18$ years & $400 \mathrm{IU}(10 \mu \mathrm{g})$ & $600 \mathrm{IU}(15 \mu \mathrm{g})$ & $4000 \mathrm{IU}(100 \mu \mathrm{g})$ & $600-1000$ & 4000 \\
\hline 19-30 years & $400 \mathrm{IU}(10 \mu \mathrm{g})$ & $600 \mathrm{IU}(15 \mu \mathrm{g})$ & $4000 \mathrm{IU}(100 \mu \mathrm{g})$ & $1500-2000$ & 10,000 \\
\hline $31-50$ years & $400 \mathrm{IU}(10 \mu \mathrm{g})$ & $600 \mathrm{IU}(15 \mu \mathrm{g})$ & $4000 \mathrm{IU}(100 \mu \mathrm{g})$ & $1500-2000$ & 10,000 \\
\hline $51-70$ years & $400 \mathrm{IU}(10 \mu \mathrm{g})$ & $600 \mathrm{IU}(15 \mu \mathrm{g})$ & $4000 \mathrm{IU}(100 \mu \mathrm{g})$ & $1500-2000$ & 10,000 \\
\hline$>70$ years & $400 \mathrm{IU}(10 \mu \mathrm{g})$ & $800 \mathrm{IU}(20 \mu \mathrm{g})$ & $4000 \mathrm{IU}(100 \mu \mathrm{g})$ & 1500-2000 & 10,000 \\
\hline \multicolumn{6}{|l|}{ Females } \\
\hline 9-13 years & $400 \mathrm{IU}(10 \mu \mathrm{g})$ & $600 \mathrm{IU}(15 \mu \mathrm{g})$ & $4000 \mathrm{IU}(100 \mu \mathrm{g})$ & $600-1000$ & 4000 \\
\hline $14-18$ years & $400 \mathrm{IU}(10 \mu \mathrm{g})$ & $600 \mathrm{IU}(15 \mu \mathrm{g})$ & $4000 \mathrm{IU}(100 \mu \mathrm{g})$ & $600-1000$ & 4000 \\
\hline 19-30 years & $400 \mathrm{IU}(10 \mu \mathrm{g})$ & $600 \mathrm{IU}(15 \mu \mathrm{g})$ & $4000 \mathrm{IU}(100 \mu \mathrm{g})$ & $1500-2000$ & 10,000 \\
\hline $31-50$ years & $400 \mathrm{IU}(10 \mu \mathrm{g})$ & $600 \mathrm{IU}(15 \mu \mathrm{g})$ & $4000 \mathrm{IU}(100 \mu \mathrm{g})$ & $1500-2000$ & 10,000 \\
\hline $51-70$ years & $400 \mathrm{IU}(10 \mu \mathrm{g})$ & $600 \mathrm{IU}(15 \mu \mathrm{g})$ & $4000 \mathrm{IU}(100 \mu \mathrm{g})$ & $1500-2000$ & 10,000 \\
\hline$>70$ years & $400 \mathrm{IU}(10 \mu \mathrm{g})$ & $800 \mathrm{IU}(20 \mu \mathrm{g})$ & $4000 \mathrm{IU}(100 \mu \mathrm{g})$ & $1500-2000$ & 10,000 \\
\hline \multicolumn{6}{|l|}{ Pregnancy } \\
\hline $14-18$ years & $400 \mathrm{IU}(10 \mu \mathrm{g})$ & $600 \mathrm{IU}(15 \mu \mathrm{g})$ & $4000 \mathrm{IU}(100 \mu \mathrm{g})$ & $600-1000$ & 4000 \\
\hline 19-30 years & $400 \mathrm{IU}(10 \mu \mathrm{g})$ & $600 \mathrm{IU}(15 \mu \mathrm{g})$ & $4000 \mathrm{IU}(100 \mu \mathrm{g})$ & $1500-2000$ & 10,000 \\
\hline $31-50$ years & $400 \mathrm{IU}(10 \mu \mathrm{g})$ & $600 \mathrm{IU}(15 \mu \mathrm{g})$ & $4000 \mathrm{IU}(100 \mu \mathrm{g})$ & $1500-2000$ & 10,000 \\
\hline \multicolumn{6}{|l|}{ Lactation * } \\
\hline 14-18 years & $400 \mathrm{IU}(10 \mu \mathrm{g})$ & $600 \mathrm{IU}(15 \mu \mathrm{g})$ & $4000 \mathrm{IU}(100 \mu \mathrm{g})$ & $600-1000$ & 4000 \\
\hline 19-30 years & $400 \mathrm{IU}(10 \mu \mathrm{g})$ & $600 \mathrm{IU}(15 \mu \mathrm{g})$ & $4000 \mathrm{IU}(100 \mu \mathrm{g})$ & $1500-2000$ & 10,000 \\
\hline $31-50$ years & $400 \mathrm{IU}(10 \mu \mathrm{g})$ & $600 \mathrm{IU}(15 \mu \mathrm{g})$ & $4000 \mathrm{IU}(100 \mu \mathrm{g})$ & $1500-2000$ & 10,000 \\
\hline
\end{tabular}

However, obese individuals, patients with malabsorption syndromes, and patients on glucocorticoids, anti-seizure and AIDS medications may require higher doses of vitamin D than individuals without these conditions [16]. The Endocrine Society's Clinical Practice Guidelines also recommended sensible sun exposure, which for most individuals is the main physiological source of vitamin D, and provided a list of the foods rich in vitamin $\mathrm{D}$, and encouraged taking a daily vitamin $\mathrm{D}$ supplement to ensure adequate $25(\mathrm{OH}) \mathrm{D}$ levels.

The Endocrine Society's Practice Guidelines also recommended treatment strategies for patients with vitamin $\mathrm{D}$ deficiency depending on age and underlying medical conditions. For vitamin D deficient infants $0-1$ years old, a treatment with $2000 \mathrm{IU} /$ day of vitamin $\mathrm{D}_{2}$ or vitamin $\mathrm{D}_{3}$ or with 50,000 IU of vitamin $D_{2}$ or vitamin $D_{3}$ once weekly for 6 weeks was suggested, followed by maintenance therapy of 400-1000 IU/day. For vitamin D deficient children aged 1-18 years who are vitamin D deficient, treatment with 2000 IU/day of vitamin $\mathrm{D}_{2}$ or vitamin $\mathrm{D}_{3}$ or with $50,000 \mathrm{IU}$ of vitamin $\mathrm{D}_{2}$ once a week, both for at least 6 weeks, was suggested, followed by maintenance therapy of 600-1000 IU/day. Vitamin D deficient adults should be treated with 50,000 IU of vitamin $\mathrm{D}_{2}$ or vitamin $\mathrm{D}_{3}$ once a week for 8 weeks or with $\sim 6000 \mathrm{IU} /$ day of vitamin $\mathrm{D}_{2}$ or vitamin $\mathrm{D}_{3}$, followed by maintenance therapy of 1500-2000 IU/day. In obese patients, patients with malabsorption syndromes, and patients on medications affecting vitamin D metabolism, two to three times higher doses are 
(at least 6000-10,000 IU/day) of vitamin D to treat vitamin D deficiency are recommended, followed by maintenance therapy of at least 3000-6000 IU/day [16]. This strategy of giving 50,000 IU of vitamin D twice monthly to treat or prevent recurrence of vitamin D deficiency or insufficiency was without any toxicity for up to six years [242] (Figure 7).

Figure 7. (A) Mean serum 25-hydroxyvitamin D [25(OH)D] levels in all patients: includes patients treated with 50,000 IU vitamin $\mathrm{D}_{2}$ every 2 weeks (maintenance therapy, $n=81$ ), including those patients with vitamin $\mathrm{D}$ insufficiency who were initially treated with 8 weeks of 50,000 IU vitamin $\mathrm{D}_{2}$ weekly prior to maintenance therapy $(n=39)$. Error bars represent standard error of the mean, mean result over 5 years shown. Time 0 is initiation of treatment, results shown as mean values averaged for 6 month intervals. When mean $25(\mathrm{OH}) \mathrm{D}$ in each 6 month group was compared to mean initial $25(\mathrm{OH}) \mathrm{D}$, a significant difference was shown with $p<0.001$ up until month 43 and $p<0.001$ when all remaining values after month 43 were compared to mean initial 25(OH)D. (B) Mean serum 25(OH)D levels in patients receiving maintenance therapy only: Levels for 37 patients who were vitamin D insufficient (25(OH)D levels $<30 \mathrm{ng} / \mathrm{mL}$ ) and 5 patients who were vitamin D sufficient $(25(\mathrm{OH}) \mathrm{D}$ levels $\geq 30 \mathrm{ng} / \mathrm{mL})$ who were treated with maintenance therapy of $50,000 \mathrm{IU}$ vitamin $\mathrm{D}_{2}$ every two weeks. Error bars represent standard error of the mean, mean result over 5 years shown. Time 0 is initiation of treatment, results shown as mean values averaged for 6 month intervals. When mean $25(\mathrm{OH}) \mathrm{D}$ in each 6 month group were compared to mean initial $25(\mathrm{OH}) \mathrm{D}$, a significant difference was shown with $p<0.001$ up until month 37 and $p<0.001$ when all remaining values after month 43 were compared to mean initial 25(OH)D. (C) Serum calcium levels: Results for all 81 patients who were treated with 50,000 IU of vitamin $\mathrm{D}_{2}$. Error bars represent standard error of the mean. Time 0 is initiation of treatment, results shown as mean values averaged for 6 month intervals. Normal serum calcium: $8.5-10.2 \mathrm{mg} / \mathrm{dL}$. Note: This figure is reproduced with permission from [242], Copyright (C 2009 American Medical Association.

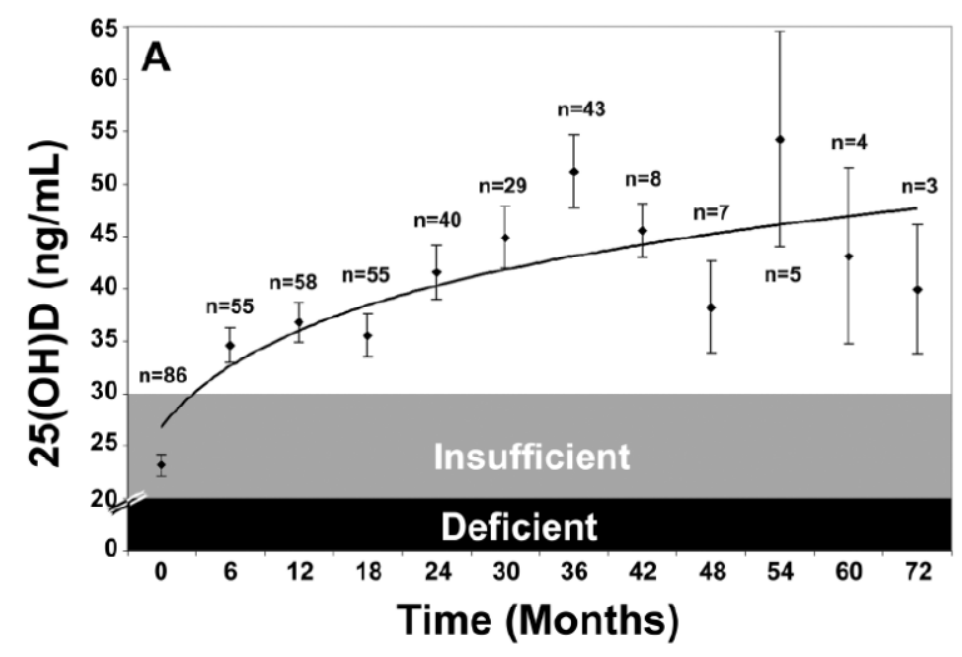


Figure 7. Cont.
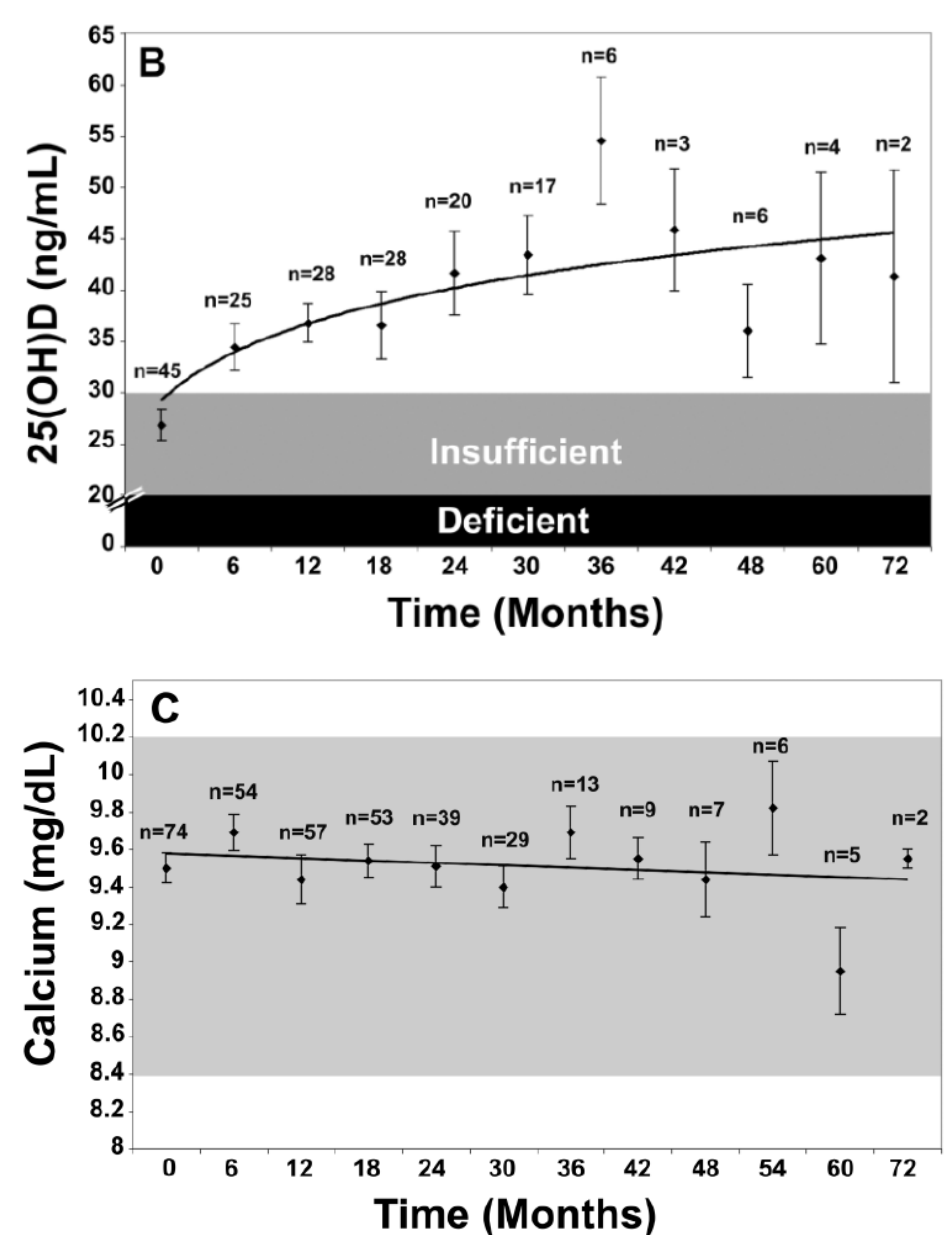

However, certain conditions like granulomatous conditions [243], genetic disorders [244] or rare polymorphisms of enzymes involved in vitamin D metabolism [245] are associated with an increased risk for vitamin D toxicity.

\section{Conclusion}

What continues to be needed are randomized controlled interventional studies with high power and using sufficiently high doses of vitamin D examining vitamin D's effects on various health outcomes.

However, the present body of evidence of experimental findings, ecological, case-control, retro- and prospective observational and interventional studies is substantial and suggests a pivotal role of vitamin D for a plethora of physiological functions and health outcomes including neuropsychiatric disorders [246], justifying the recommendation to enhance children's and adults' vitamin D status by following recommendations for sensible sun exposure, ingesting foods that contain vitamin D and vitamin D supplementation. Increasing the vitamin D status worldwide in the general adult and children population without rare conditions associated with an increased risk for vitamin D toxicity will help improve their overall health and well-being (Figure 6). 


\section{Acknowledgements}

This work was supported in part by the UV Foundation (2880 Zanker Road, Suite 203, San Jose, CA 95134, USA) and the Mushroom Council (6620 Fletcher Lane, McLean, VA, USA).

\section{Conflict of Interest}

The authors declare no conflict of interest.

\section{References}

1. Holick, M. Phylogenetic and Evolutionary Aspects of Vitamin D from Phytoplankton to Humans. In Verebrate Endocrinology: Fundamentals and Biomedical Implications; Pang, P.K.T., Schreibman, M.P., Eds.; Academic Press, Inc.: Orlando, FL, USA, 1989.

2. Holick, M.F. Vitamin D: Evolutionary, physiological and health perspectives. Curr. Drug Targets 2011, 12, 4-18.

3. Yoshida, T.; Stern, P.H. How vitamin D works on bone. Endocrinol. Metab. Clin. North Am. 2012, 41, 557-569.

4. Sai, A.J.; Walters, R.W.; Fang, X.; Gallagher, J.C. Relationship between vitamin D, parathyroid hormone, and bone health. J. Clin. Endocrinol. Metab. 2011, 96, E436-E446.

5. Lips, P.; van Schoor, N.M. The effect of vitamin D on bone and osteoporosis. Best Pract. Res. Clin. Endocrinol. Metab. 2011, 25, 585-591.

6. Nagpal, S.; Na, S.; Rathnachalam, R. Noncalcemic actions of vitamin D receptor ligands. Endocr. Rev. 2005, 26, 662-687.

7. Holick, M.F. Vitamin D deficiency. N. Engl. J. Med. 2007, 357, 266-281.

8. Jablonski, N.G.; Chaplin, G. The evolution of human skin coloration. J. Hum. Evol. 2000, 39, 57-106.

9. Ergocalciferol. Available online: http://www.chemspider.com/Chemical-Structure.4444351.html (accessed on 21 December 2012).

10. Cholecalciferol. Available online: http://www.chemspider.com/Chemical-Structure.9058792.html (accessed on 21 December 2012).

11. Holick, M.F.; Tian, X.Q.; Allen, M. Evolutionary importance for the membrane enhancement of the production of vitamin $\mathrm{D}_{3}$ in the skin of poikilothermic animals. Proc. Natl. Acad. Sci. USA 1995, 92, 3124-3126.

12. Tian, X.Q.; Chen, T.C.; Matsuoka, L.Y.; Wortsman, J.; Holick, M.F. Kinetic and thermodynamic studies of the conversion of previtamin $\mathrm{D}_{3}$ to vitamin $\mathrm{D}_{3}$ in human skin. J. Biol. Chem. 1993, 268, 14888-14892.

13. Chen, T.; Lu, Z.; Holick, M. Photobiology of Vitamin D. In Vitamin D: Physiology, Molecular Biology, and Clinical Applications, 2nd ed.; Holick, M.F., Ed.; Humana Press: New York, NY, USA, 2010; pp. 35-60.

14. Holick, M.F. Resurrection of vitamin D deficiency and rickets. J. Clin. Invest. 2006, 116, 2062-2072. 
15. Jones, G. Phosphorus metabolism and management in chronic kidney disease: Expanding role for vitamin D in chronic kidney disease: Importance of blood 25-OH-D levels and extra-renal $1 \alpha$-hydroxylase in the classical and nonclassical actions of $1 \alpha, 25$-dihydroxyvitamin $\mathrm{D}_{3}$. Semin. Dial. 2007, 20, 316-324.

16. Holick, M.F.; Binkley, N.C.; Bischoff-Ferrari, H.A.; Gordon, C.M.; Hanley, D.A.; Heaney, R.P.; Murad, M.H.; Weaver, C.M. Evaluation, treatment, and prevention of vitamin D deficiency: An endocrine society clinical practice guideline. J. Clin. Endocrinol. Metab. 2011, 96, 1911-1930.

17. Holick, M.F. Vitamin D and health: Evolution, biologic functions, and recommended dietary intakes for vitamin D. Clin. Rev. Bone Miner. Metab. 2009, 7, 2-19.

18. Bosworth, C.R.; Levin, G.; Robinson-Cohen, C.; Hoofnagle, A.N.; Ruzinski, J.; Young, B.; Schwartz, S.M.; Himmelfarb, J.; Kestenbaum, B.; de Boer, I.H. The serum 24,25-dihydroxyvitamin D concentration, a marker of vitamin D catabolism, is reduced in chronic kidney disease. Kidney Int. 2012, 92, 693-700.

19. Christakos, S.; Dhawan, P.; Porta, A.; Mady, L.J.; Seth, T. Vitamin D and intestinal calcium absorption. Mol. Cell. Endocrinol. 2011, 347, 25-29.

20. Christakos, S. Recent advances in our understanding of 1,25-dihydroxyvitamin $\mathrm{D}_{3}$ regulation of intestinal calcium absorption. Arch. Biochem. Biophys. 2012, 523, 73-76.

21. Holick, M.F. The vitamin D deficiency pandemic: A forgotten hormone important for health. Public Health Rev. 2010, 32, 267-283.

22. Holick, M.F. Environmental factors that influence the cutaneous production of vitamin D. Am. J. Clin. Nutr. 1995, 61, 638S-645S.

23. Holick, M.F.; Chen, T.C. Vitamin D deficiency: A worldwide problem with health consequences. Am. J. Clin. Nutr. 2008, 87, 1080S-1086S.

24. Urbain, P.; Singler, F.; Ihorst, G.; Biesalski, H.K.; Bertz, H. Bioavailability of vitamin $\mathrm{D}_{2}$ from UV-B-irradiated button mushrooms in healthy adults deficient in serum 25-hydroxyvitamin D: A randomized controlled trial. Eur. J. Clin. Nutr. 2011, 65, 965-971.

25. Mau, J.-L.; Chen, P.-R.; Yang, J.-H. Ultraviolet irradiation increased vitamin $\mathrm{D}_{2}$ content in edible mushrooms. J. Agric. Food Chem. 1998, 46, 5269-5272.

26. Tangpricha, V.; Koutkia, P.; Rieke, S.M.; Chen, T.C.; Perez, A.A.; Holick, M.F. Fortification of orange juice with vitamin D: A novel approach for enhancing vitamin D nutritional health. Am. J. Clin. Nutr. 2003, 77, 1478-1483.

27. Hypercalcaemia in infants and vitamin D. Br. Med. J. 1956, 2, 149.

28. Holick, M.F. Sunlight and vitamin D for bone health and prevention of autoimmune diseases, cancers, and cardiovascular disease. Am. J. Clin. Nutr. 2004, 80, 1678S-1688S.

29. Biancuzzo, R.M.; Young, A.; Bibuld, D.; Cai, M.H.; Winter, M.R.; Klein, E.K.; Ameri, A.; Reitz, R.; Salameh, W.; Chen, T.C.; Holick, M.F. Fortification of orange juice with vitamin $\mathrm{D}_{2}$ or vitamin $\mathrm{D}_{3}$ is as effective as an oral supplement in maintaining vitamin $\mathrm{D}$ status in adults. Am. J. Clin. Nutr. 2010, 91, 1621-1626.

30. Armas, L.A.G.; Hollis, B.W.; Heaney, R.P. Vitamin $\mathrm{D}_{2}$ is much less effective than vitamin $\mathrm{D}_{3}$ in humans. J. Clin. Endocrinol. Metab. 2004, 89, 5387-5391. 
31. Trang, H.M.; Cole, D.E.; Rubin, L.A.; Pierratos, A.; Siu, S.; Vieth, R. Evidence that vitamin $\mathrm{D}_{3}$ increases serum 25-hydroxyvitamin $\mathrm{D}$ more efficiently than does vitamin $\mathrm{D}_{2}$. Am. J. Clin. Nutr. 1998, 68, 854-858.

32. Houghton, L.A.; Vieth, R. The case against ergocalciferol (vitamin $\mathrm{D}_{2}$ ) as a vitamin supplement. Am. J. Clin. Nutr. 2006, 84, 694-697.

33. Romagnoli, E.; Mascia, M.L.; Cipriani, C.; Fassino, V.; Mazzei, F.; D’Erasmo, E.; Carnevale, V.; Scillitani, A.; Minisola, S. Short and long-term variations in serum calciotropic hormones after a single very large dose of ergocalciferol (vitamin $\mathrm{D}_{2}$ ) or cholecalciferol (vitamin $\mathrm{D}_{3}$ ) in the elderly. J. Clin. Endocrinol. Metab. 2008, 93, 3015-3020.

34. Heaney, R.P.; Recker, R.R.; Grote, J.; Horst, R.L.; Armas, L.A.G. Vitamin $\mathrm{D}_{3}$ is more potent than vitamin $\mathrm{D}_{2}$ in humans. J. Clin. Endocrinol. Metab. 2011, 96, E447-E452.

35. Leventis, P.; Kiely, P.D. The tolerability and biochemical effects of high-dose bolus vitamin $\mathrm{D}_{2}$ and $\mathrm{D}_{3}$ supplementation in patients with vitamin D insufficiency. Scand. J. Rheumatol. 2009, 38, 149-153.

36. Tripkovic, L.; Lambert, H.; Hart, K.; Smith, C.P.; Bucca, G.; Penson, S.; Chope, G.; Hyppönen, E.; Berry, J.; Vieth, R.; Lanham-New, S. Comparison of vitamin $\mathrm{D}_{2}$ and vitamin $\mathrm{D}_{3}$ supplementation in raising serum 25-hydroxyvitamin D status: A systematic review and meta-analysis. Am. J. Clin. Nutr. 2012, 95, 1357-1364.

37. Holick, M.F.; Biancuzzo, R.M.; Chen, T.C.; Klein, E.K.; Young, A.; Bibuld, D.; Reitz, R.; Salameh, W.; Ameri, A.; Tannenbaum, A.D. Vitamin $\mathrm{D}_{2}$ is as effective as vitamin $\mathrm{D}_{3}$ in maintaining circulating concentrations of 25-hydroxyvitamin D. J. Clin. Endocrinol. Metab. 2008, 93, 677-681.

38. Thacher, T.D.; Obadofin, M.O.; O’Brien, K.O.; Abrams, S.A. The Effect of vitamin $\mathrm{D}_{2}$ and vitamin $\mathrm{D}_{3}$ on intestinal calcium absorption in Nigerian children with rickets. J. Clin. Endocrinol. Metab. 2009, 94, 3314-3321.

39. Gordon, C.M.; Williams, A.L.; Feldman, H.A.; May, J.; Sinclair, L.; Vasquez, A.; Cox, J.E. Treatment of hypovitaminosis D in infants and toddlers. J. Clin. Endocrinol. Metab. 2008, 93, 2716-2721.

40. Rapuri, P.B.; Gallagher, J.C.; Haynatzki, G. Effect of vitamins $\mathrm{D}_{2}$ and $\mathrm{D}_{3}$ supplement use on serum 25OHD concentration in elderly women in summer and winter. Calcif. Tissue Int. 2004, 74, 150-156.

41. Hollis, B. Assessment of vitamin D nutritional and hormonal status: What to measure and how to do it. Calcif. Tissue Int.1996, 58, 4-5.

42. DeLuca, H.F. Overview of general physiologic features and functions of vitamin D. Am. J. Clin. Nutr. 2004, 80, 1689S-1696S.

43. Zehnder, D.; Bland, R.; Williams, M.C.; McNinch, R.W.; Howie, A.J.; Stewart, P.M.; Hewison, M. Extrarenal expression of 25-hydroxyvitamin $\mathrm{D}(3) 1$ alpha-hydroxylase. J. Clin. Endocrinol. Metab. 2001, 86, 888-894.

44. Lehmann, B.; Meurer, M. Vitamin D metabolism. Dermatol. Ther. 2010, 23, 2-12.

45. Ritter, C.S.; Haughey, B.H.; Armbrecht, H.J.; Brown, A.J. Distribution and regulation of the 25-hydroxyvitamin D3 1 $\alpha$-hydroxylase in human parathyroid glands. J. Steroid Biochem. Mol. Biol. 2012, 130, 73-80. 
46. Rosen, C.J.; Adams, J.S.; Bikle, D.D.; Black, D.M.; Demay, M.B.; Manson, J.E.; Murad, M.H.; Kovacs, C.S. The nonskeletal effects of vitamin D: An endocrine society scientific statement. Endocr. Rev. 2012, 33, 456-492.

47. Carlberg, C.; Bendik, I.; Wyss, A.; Meier, E.; Sturzenbecker, L.J.; Grippo, J.F.; Hunziker, W. Two nuclear signalling pathways for vitamin D. Nature 1993, 361, 657-660.

48. McKenna, N.J.; Lanz, R.B.; O’Malley, B.W. Nuclear receptor coregulators: Cellular and molecular biology. Endocr. Rev. 1999, 20, 321-344.

49. Smith, C.L.; O’Malley, B.W. Coregulator function: A key to understanding tissue specificity of selective receptor modulators. Endocr. Rev. 2004, 25, 45-71.

50. Dunlop, T.W.; Vaisanen, S.; Frank, C.; Carlberg, C. The genes of the coactivator TIF2 and the corepressor SMRT are primary 1alpha,25(OH)2D3 targets. J. Steroid Biochem. Mol. Biol. 2004, 89-90, 257-260.

51. Fleet, J.C. Vitamin D receptors: Not just in the nucleus anymore. Nutr. Rev. 1999, 57, 60-62.

52. Norman, A.W. Minireview: Vitamin D receptor: New assignments for an already busy receptor. Endocrinology 2006, 147, 5542-5548.

53. Institute of Medicine of the National Academies. Dietary Reference Intakes for Calcium and Vitamin D; Catharine Ross, A., Taylor, C.L., Yaktine, A.L., Eds.; The National Academy of Sciences: Washington, DC, USA, 2011.

54. Chapuy, M.C.; Schott, A.M.; Garnero, P.; Hans, D.; Delmas, P.D.; Meunier, P.J. Healthy elderly French women living at home have secondary hyperparathyroidism and high bone turnover in winter. EPIDOS Study Group. J. Clin. Endocrinol. Metab. 1996, 81, 1129-1133.

55. Holick, M.F.; Siris, E.S.; Binkley, N.; Beard, M.K.; Khan, A.; Katzer, J.T.; Petruschke, R.A.; Chen, E.; de Papp, A.E. Prevalence of vitamin D inadequacy among postmenopausal north American women receiving osteoporosis therapy. J. Clin. Endocrinol. Metab. 2005, 90, 3215-3224.

56. Thomas, M.K.; Lloyd-Jones, D.M.; Thadhani, R.I.; Shaw, A.C.; Deraska, D.J.; Kitch, B.T.; Vamvakas, E.C.; Dick, I.M.; Prince, R.L.; Finkelstein, J.S. Hypovitaminosis D in medical inpatients. N. Engl. J. Med. 1998, 338, 777-783.

57. Valcour, A.; Blocki, F.; Hawkins, D.M.; Rao, S.D. Effects of age and serum 25-OH-vitamin D on serum parathyroid hormone levels. J. Clin. Endocrinol. Metab. 2012, 97, 3989-3995.

58. Whiting, S.J.; Langlois, K.A.; Vatanparast, H.; Greene-Finestone, L.S. The vitamin D status of Canadians relative to the 2011 Dietary Reference Intakes: An examination in children and adults with and without supplement use. Am. J. Clin. Nutr. 2011, 94, 128-135.

59. Hanley, D.A.; Cranney, A.; Jones, G.; Whiting, S.J.; Leslie, W.D.; Cole, D.E.; Atkinson, S.A.; Josse, R.G.; Feldman, S.; Kline, G.A.; Rosen, C. Vitamin D in adult health and disease: A review and guideline statement from Osteoporosis Canada. CMAJ 2010, 182, E610-E618.

60. Holick, M.F.; Binkley, N.C.; Bischoff-Ferrari, H.A.; Gordon, C.M.; Hanley, D.A.; Heaney, R.P.; Murad, M.H.; Weaver, C.M. Guidelines for preventing and treating vitamin D deficiency and insufficiency revisited. J. Clin. Endocrinol. Metab. 2012, 97, 1153-1158.

61. Looker, A.C.; Johnson, C.L.; Lacher, D.A.; Pfeiffer, C.M.; Schleicher, R.L.; Sempos, C.T. Vitamin D status: United States, 2001-2006. NCHS Data Brief 2011, 59, 1-8. 
62. Marwaha, R.K.; Tandon, N.; Reddy, D.R.H.; Aggarwal, R.; Singh, R.; Sawhney, R.C.; Saluja, B.; Ganie, M.A.; Singh, S. Vitamin D and bone mineral density status of healthy schoolchildren in northern India. Am. J. Clin. Nutr. 2005, 82, 477-482.

63. Sachan, A.; Gupta, R.; Das, V.; Agarwal, A.; Awasthi, P.K.; Bhatia, V. High prevalence of vitamin D deficiency among pregnant women and their newborns in northern India. Am. J. Clin. Nutr. 2005, 81, 1060-1064.

64. Prentice, A.; Schoenmakers, I.; Jones, K.; Jarjou, L.; Goldberg, G. Vitamin D deficiency and its health consequences in Africa. Clin. Rev. Bone Miner. Metab. 2009, 7, 94-106.

65. Van der Mei, I.A.; Ponsonby, A.L.; Engelsen, O.; Pasco, J.A.; McGrath, J.J.; Eyles, D.W.; Blizzard, L.; Dwyer, T.; Lucas, R.; Jones, G. The high prevalence of vitamin D insufficiency across Australian populations is only partly explained by season and latitude. Environ. Health Perspect. 2007, 115, 1132-1139.

66. Maeda, S.S.; Kunii, I.S.; Hayashi, L.; Lazaretti-Castro, M. The effect of sun exposure on 25-hydroxyvitamin D concentrations in young healthy subjects living in the city of Sao Paulo, Brazil. Braz. J. Med. Biol. Res. 2007, 40, 1653-1659.

67. Sedrani, S.H. Low 25-hydroxyvitamin D and normal serum calcium concentrations in Saudi Arabia: Riyadh region. Ann. Nutr. Metab. 1984, 28, 181-185.

68. El-Hajj Fuleihan, G. Vitamin D Deficiency in the Middle East and Its Health Consequences. In Vitamin D: Physiology, Molecular Biology, and Clinical Applications; Holick, M.F., Ed.; Humana Press: New York, NY, USA, 2010; pp. 469-494.

69. Rich-Edwards, J.W.; Ganmaa, D.; Kleinman, K.; Sumberzul, N.; Holick, M.F.; Lkhagvasuren, T.; Dulguun, B.; Burke, A.; Frazier, A.L. Randomized trial of fortified milk and supplements to raise 25-hydroxyvitamin D concentrations in schoolchildren in Mongolia. Am. J. Clin. Nutr. 2011, 94, 578-584.

70. Rockell, J.; Skeaff, C.; Williams, S.; Green, T. Serum 25-hydroxyvitamin D concentrations of New Zealanders aged 15 years and older. Osteoporos. Int. 2006, 17, 1382-1389.

71. Prentice, A. Vitamin D deficiency: A global perspective. Nutr. Rev. 2008, 66, S153-S164.

72. Marks, J.; Srai, S.K.; Biber, J.; Murer, H.; Unwin, R.J.; Debnam, E.S. Intestinal phosphate absorption and the effect of vitamin D: A comparison of rats with mice. Exp. Physiol. 2006, 91, 531-537.

73. Chen, T.C.; Castillo, L.; Korycka-Dahl, M.; DeLuca, H.F. Role of vitamin D metabolites in phosphate transport of rat intestine. J. Nutr. 1974, 104, 1056-1060.

74. Segersten, U.; Correa, P.; Hewison, M.; Hellman, P.; Dralle, H.; Carling, T.; Åkerström, G.; Westin, G. 25-Hydroxyvitamin D(3)-1 $\alpha$-hydroxylase expression in normal and pathological parathyroid glands. J. Clin. Endocrinol. Metab. 2002, 87, 2967-2972.

75. Ritter, C.S.; Armbrecht, H.J.; Slatopolsky, E.; Brown, A.J. 25-Hydroxyvitamin D3 suppresses PTH synthesis and secretion by bovine parathyroid cells. Kidney Int. 2006, 70, 654-659.

76. Rajakumar, K. Vitamin D, cod-liver oil, sunlight, and rickets: A historical perspective. Pediatrics 2003, 112, e132-e135.

77. Mozołowski, W. Jędrzej Sniadecki (1768-1838) on the cure of rickets. Nature 1939, 143, 121.

78. Palm, T.A. The geographical distribution and etiology of rickets. Practitioner 1890, 45, 270-342. 
79. Huldschinsky, K. Heilung von Rachitis durch künstliche Höhensonne. Dtsch. Med. Wochenschr. 1919, 45, 712-713.

80. Huldschinsky, K. The Ultra-Violet Light Treatment of Rickets; Alpine Press: Newark, NJ, USA, 1928; pp. 3-19.

81. Mellanby, T. The part played by an "accessory factor" in the production of experimental rickets. J. Physiol. 1918, 52, 11-14.

82. McCollum, E.F.; Simmonds, N.; Becker, J.E.; Shipley, P.G. Studies on experimental rickets; and experimental demonstration of the existence of a vitamin which promotes calcium deposition. J. Biol. Chem. 1922, 53, 293-312.

83. Hess, A.F.; Weinstock, M. Antirachitic properties imparted to inert fluids and to green vegetables by ultraviolet irradiation. J. Biol. Chem. 1924, 62, 301-313.

84. Steenbock, H.; Black, A. The reduction of growth-promoting and calcifying properties in a ration by exposure to ultraviolet light. J. Biol. Chem. 1924, 61, 408-422.

85. Cooper, C.; Javaid, K.; Westlake, S.; Harvey, N.; Dennison, E. Developmental origins of osteoporotic fracture: The role of maternal vitamin D insufficiency. J. Nutr. 2005, 135, 2728S-2734S.

86. Javaid, M.K.; Crozier, S.R.; Harvey, N.C.; Gale, C.R.; Dennison, E.M.; Boucher, B.J.; Arden, N.K.; Godfrey, K.M.; Cooper, C. Maternal vitamin D status during pregnancy and childhood bone mass at age 9 years: A longitudinal study. Lancet 2006, 367, 36-43.

87. Holick, M.F. Vitamin D and bone health. J. Nutr. 1996, 126, 1159S-1164S.

88. Adams, J.S.; Hewison, M. Update in vitamin D. J. Clin. Endocrinol. Metab. 2010, 95, 471-478.

89. Bischoff-Ferrari, H.A.; Kiel, D.P.; Dawson-Hughes, B.; Orav, J.E.; Li, R.; Spiegelman, D.; Dietrich, T.; Willett, W.C. Dietary calcium and serum 25-hydroxyvitamin D status in relation to BMD among U.S. adults. J. Bone Miner. Res. 2009, 24, 935-942.

90. Delling, G. Endokrine Osteopathien; Morphologie, Histomorphometrie und Differentialdiagnose. Endocrine Bone Diseases; Morphology, Histomorphometry and Differential Diagnosis; Fischer: Stuttgart, Germany, 1975.

91. Priemel, M.; von Domarus, C.; Klatte, T.O.; Kessler, S.; Schlie, J.; Meier, S.; Proksch, N.; Pastor, F.; Netter, C.; Streichert, T.; et al. Bone mineralization defects and vitamin D deficiency: Histomorphometric analysis of iliac crest bone biopsies and circulating 25-hydroxyvitamin D in 675 patients. J. Bone Miner. Res. 2010, 25, 305-312.

92. Holick, M.F. Vitamin D: Importance in the prevention of cancers, type 1 diabetes, heart disease, and osteoporosis. Am. J. Clin. Nutr. 2004, 79, 362-371.

93. Holick, M.F. Optimal vitamin D status for the prevention and treatment of osteoporosis. Drugs Aging 2007, 24, 1017-1029.

94. Becker, D.; Kilgore, M.; Morrisey, M. The societal burden of osteoporosis. Curr. Rheumatol. Rep. 2010, 12, 186-191.

95. Khosla, S.; Amin, S.; Orwoll, E. Osteoporosis in Men. Endocr. Rev. 2008, 29, 441-464.

96. Dawson-Hughes, B.; Heaney, R.P.; Holick, M.F.; Lips, P.; Meunier, P.J.; Vieth, R. Estimates of optimal vitamin D status. Osteoporos. Int. 2005, 16, 713-716. 
97. Cauley, J.A.; LaCroix, A.Z.; Wu, L.; Horwitz, M.; Danielson, M.E.; Bauer, D.C.; Lee, J.S.; Jackson, R.D.; Robbins, J.A.; Wu, C.; et al. Serum 25-hydroxyvitamin D concentrations and risk for hip fractures. Ann. Int. Med. 2008, 149, 242-250.

98. Bischoff-Ferrari, H.A.; Willett, W.C.; Orav, E.J.; Lips, P.; Meunier, P.J.; Lyons, R.A.; Flicker, L.; Wark, J.; Jackson, R.D.; Cauley, J.A.; et al. A pooled analysis of vitamin D dose requirements for fracture prevention. N. Engl. J. Med. 2012, 367, 40-49.

99. Chapuy, M.C.; Arlot, M.E.; Duboeuf, F.; Brun, J.; Crouzet, B.; Arnaud, S.; Delmas, P.D.; Meunier, P.J. Vitamin $\mathrm{D}_{3}$ and calcium to prevent hip fractures in elderly women. N. Engl. J. Med. 1992, 327, 1637-1642.

100. Grant, A.M.; Avenell, A.; Campbell, M.K.; McDonald, A.M.; MacLennan, G.S.; McPherson, G.C.; Anderson, F.H.; Cooper, C.; Francis, R.M.; Donaldson, C.; et al. Null Oral vitamin $\mathrm{D}_{3}$ and calcium for secondary prevention of low-trauma fractures in elderly people (Randomised Evaluation of Calcium Or vitamin D, RECORD): A randomised placebo-controlled trial. Lancet 2005, 365, 1621-1628.

101. Dawson-Hughes, B.; Harris, S.S.; Krall, E.A.; Dallal, G.E. Effect of calcium and vitamin D supplementation on bone density in men and women 65 years of age or older. N. Engl. J. Med. 1997, 337, 670-676.

102. Lips, P.; Graafmans, W.C.; Ooms, M.E.; Bezemer, P.D.; Bouter, L.M. Vitamin D supplementation and fracture incidence in elderly persons. A randomized, placebo-controlled clinical trial. Ann. Int. Med. 1996, 124, 400-406.

103. Meyer, H.E.; Smedshaug, G.B.; Kvaavik, E.; Falch, J.A.; Tverdal, A.; Pedersen, J.I. Can vitamin D supplementation reduce the risk of fracture in the elderly? A randomized controlled trial. J. Bone Miner. Res. 2002, 17, 709-715.

104. Jackson, R.D.; LaCroix, A.Z.; Gass, M.; Wallace, R.B.; Robbins, J.; Lewis, C.E.; Bassford, T.; Beresford, S.A.A.; Black, H.R.; Blanchette, P.; et al. Calcium plus vitamin D supplementation and the risk of fractures. N. Engl. J. Med. 2006, 354, 669-683.

105. Pfeifer, M.; Begerow, B.; Minne, H.W.; Abrams, C.; Nachtigall, D.; Hansen, C. Effects of a short-term vitamin $\mathrm{D}$ and calcium supplementation on body sway and secondary hyperparathyroidism in elderly women. J. Bone Miner. Res. 2000, 15, 1113-1118.

106. Pfeifer, M.; Begerow, B.; Minne, H.W.; Suppan, K.; Fahrleitner-Pammer, A.; Dobnig, H. Effects of a long-term vitamin $\mathrm{D}$ and calcium supplementation on falls and parameters of muscle function in community-dwelling older individuals. Osteoporos. Int. 2009, 20, 315-322.

107. Bischoff-Ferrari, H. Relevance of vitamin D in muscle health. Rev. Endocr. Metab. Disord. 2012, $13,71-77$.

108. Srikuea, R.; Zhang, X.; Park-Sarge, O.-K.; Esser, K.A. VDR and CYP27B1 are expressed in $\mathrm{C} 2 \mathrm{C} 12$ cells and regenerating skeletal muscle: Potential role in suppression of myoblast proliferation. Am. J. Physiol. Cell Physiol. 2012, 303, C396-C405.

109. Ceglia, L.; Harris, S.S. Vitamin D and its role in skeletal muscle. Calcif. Tissue Int. 2012, doi:10.1007/s00223-012-9645-y.

110. Simpson, R.U.; Thomas, G.A.; Arnold, A.J. Identification of 1,25-dihydroxyvitamin D3 receptors and activities in muscle. J. Biol. Chem. 1985, 260, 8882-8891. 
111. Bischoff, H.A.; Borchers, M.; Gudat, F.; Duermueller, U.; Theiler, R.; Stähelin, H.B.; Dick, W. In situ detection of 1,25-dihydroxyvitamin D3 receptor in human skeletal muscle tissue. Histochem. J. 2001, 33, 19-24.

112. Costa, E.M.; Blau, H.M.; Feldman, D. 1,25-Dihydroxyvitamin D3 receptors and hormonal responses in cloned human skeletal muscle cells. Endocrinology 1986, 119, 2214-2220.

113. Boland, R.; Norman, A.; Ritz, E.; Hasselbach, W. Presence of a 1,25-dihydroxy-vitamin D3 receptor in chick skeletal muscle myoblasts. Biochem. Biophys. Res. Commun. 1985, 128, 305-311.

114. Pfeifer, M.; Begerow, B.; Minne, H.W. Vitamin D and muscle function. Osteoporos. Int. 2002, 13, 187-194.

115. Janssen, H.C.; Samson, M.M.; Verhaar, H.J. Vitamin D deficiency, muscle function, and falls in elderly people. Am. J. Clin. Nutr. 2002, 75, 611-615.

116. Lou, Y.-R.; Molnár, F.; Peräkylä, M.; Qiao, S.; Kalueff, A.V.; St-Arnaud, R.; Carlberg, C.; Tuohimaa, P. 25-Hydroxyvitamin $\mathrm{D}(3)$ is an agonistic vitamin D receptor ligand. J. Steroid Biochem. Mol. Biol. 2010, 118, 162-170.

117. Wang, Y.; DeLuca, H.F. Is the vitamin D receptor found in muscle? Endocrinology 2011, 152, 354-363.

118. Schott, G.D.; Wills, M.R. Muscle weakness in osteomalacia. Lancet 1976, 307, 626-629.

119. Bischoff-Ferrari, H.A.; Giovannucci, E.; Willett, W.C.; Dietrich, T.; Dawson-Hughes, B. Estimation of optimal serum concentrations of 25-hydroxyvitamin D for multiple health outcomes. Am. J. Clin. Nutr. 2006, 84, 18-28.

120. Glerup, H.; Mikkelsen, K.; Poulsen, L.; Hass, E.; Overbeck, S.; Andersen, H.; Charles, P.; Eriksen, E.F. Hypovitaminosis D myopathy without biochemical signs of osteomalacic bone involvement. Calcif. Tissue Int. 2000, 66, 419-424.

121. Wicherts, I.S.; van Schoor, N.M.; Boeke, A.J.P.; Visser, M.; Deeg, D.J.H.; Smit, J.; Knol, D.L.; Lips, P. Vitamin D status predicts physical performance and its decline in older persons. J. Clin. Endocrinol. Metab. 2007, 92, 2058-2065.

122. Bischoff-Ferrari, H.A.; Dietrich, T.; Orav, E.J.; Hu, F.B.; Zhang, Y.; Karlson, E.W.; Dawson-Hughes, B. Higher 25-hydroxyvitamin D concentrations are associated with better lower-extremity function in both active and inactive persons aged $\geq 60$ y. Am. J. Clin. Nutr. 2004, $80,752-758$.

123. Bischoff, H.A.; Stähelin, H.B.; Dick, W.; Akos, R.; Knecht, M.; Salis, C.; Nebiker, M.; Theiler, R.; Pfeifer, M.; Begerow, B.; et al. Effects of vitamin D and calcium supplementation on falls: A randomized controlled trial. J. Bone Miner. Res. 2003, 18, 343-351.

124. Bischoff-Ferrari, H.; Conzelmann, M.; Stähelin, H.; Dick, W.; Carpenter, M.; Adkin, A.; Theiler, R.; Pfeifer, M.; Allum, J. Is fall prevention by vitamin D mediated by a change in postural or dynamic balance? Osteoporos. Int. 2006, 17, 656-663.

125. Broe, K.E.; Chen, T.C.; Weinberg, J.; Bischoff-Ferrari, H.A.; Holick, M.F.; Kiel, D.P. A higher dose of vitamin D reduces the risk of falls in nursing home residents: A randomized, multiple-dose study. J. Am. Geriatr. Soc. 2007, 55, 234-239.

126. Bischoff-Ferrari, H.A.; Dawson-Hughes, B.; Staehelin, H.B.; Orav, J.E.; Stuck, A.E.; Theiler, R.; Wong, J.B.; Egli, A.; Kiel, D.P.; Henschkowski, J. Fall prevention with supplemental and active 
forms of vitamin D: A meta-analysis of randomised controlled trials. BMJ 2009, 339, doi:10.1136/bmj.b3692.

127. Apperly, F.L. The relation of solar radiation to cancer mortality in north America. Cancer Res. 1941, 1, 191-195.

128. Garland, C.F.; Garland, F.F. Do sunlight and vitamin D reduce the likelihood of colon cancer? Int. J. Epidemiol. 1980, 9, 227-231.

129. Grant, W.B. Ecological studies of the UVB-vitamin D-cancer hypothesis. Anticancer Res. 2012, 32, 223-236.

130. Drake, M.T.; Maurer, M.J.; Link, B.K.; Habermann, T.M.; Ansell, S.M.; Micallef, I.N.; Kelly, J.L.; Macon, W.R.; Nowakowski, G.S.; Inwards, D.J.; et al. Vitamin D insufficiency and prognosis in non-Hodgkin's lymphoma. J. Clin. Oncol. 2010, 28, 4191-4198.

131. Freedman, D.M.; Looker, A.C.; Chang, S.-C.; Graubard, B.I. Prospective study of serum vitamin D and cancer mortality in the United States. J. Natl. Cancer Inst. 2007, 99, 1594-1602.

132. Garland, C.F.; Garland, F.C.; Shaw, E.K.; Comstock, G.W.; Helsing, K.J.; Gorham, E.D. Serum 25-hydroxyvitamin D and colon cancer: Eight-year prospective study. Lancet 1989, 334, 1176-1178.

133. Garland, C.; Shekelle, R.B.; Barrett-Connor, E.; Criqui, M.H.; Rossof, A.H.; Paul, O. Dietary vitamin D and calcium and risk of colorectal cancer: A 19 -year prospective study in men. Lancet 1985, 1, 307-309.

134. Garland, C.F.; Garland, F.C.; Gorham, E.D.; Lipkin, M.; Newmark, H.; Mohr, S.B.; Holick, M.F. The role of itamin D in cancer prevention. Am. J. Public Health 2006, 96, 252-261.

135. Giovannucci, E.; Liu, Y.; Rimm, E.B.; Hollis, B.W.; Fuchs, C.S.; Stampfer, M.J.; Willett, W.C. Prospective study of predictors of vitamin D status and cancer incidence and mortality in men. J. Natl. Cancer Inst. 2006, 98, 451-459.

136. John, E.M.; Schwartz, G.G.; Dreon, D.M.; Koo, J. Vitamin D and breast cancer risk: The NHANES I Epidemiologic Follow-up Study, 1971-1975 to 1992. National Health and Nutrition Examination Survey. Cancer Epidemiol. Biomarkers Prev. 1999, 8, 399-406.

137. Lappe, J.M.; Travers-Gustafson, D.; Davies, K.M.; Recker, R.R.; Heaney, R.P. Vitamin D and calcium supplementation reduces cancer risk: Results of a randomized trial. Am. J. Clin. Nutr. 2007, 85, 1586-1591.

138. Manson, J.E.; Mayne, S.T.; Clinton, S.K. Vitamin D and prevention of cancer-Ready for prime time? N. Engl. J. Med. 2011, 364, 1385-1387.

139. Shin, M.-H.; Holmes, M.D.; Hankinson, S.E.; Wu, K.; Colditz, G.A.; Willett, W.C. Intake of dairy products, calcium, and vitamin D and risk of breast cancer. J. Natl. Cancer Inst. 2002, 94, 1301-1310.

140. Feskanich, D.; Ma, J.; Fuchs, C.S.; Kirkner, G.J.; Hankinson, S.E.; Hollis, B.W.; Giovannucci, E.L. Plasma vitamin D metabolites and risk of colorectal cancer in women. Cancer Epidemiol. Biomarkers Prev. 2004, 13, 1502-1508.

141. Krishnan, A.V.; Feldman, D. Mechanisms of the anti-cancer and anti-inflammatory actions of vitamin D. Annu. Rev. Pharmacol. Toxicol. 2011, 51, 311-336.

142. Fleet, J.C.; Desmet, M.; Johnson, R.; Li, Y. Vitamin D and cancer: A review of molecular mechanisms. Biochem. J. 2012, 441, 61-76. 
143. Vazirnia, A.; Liu, P.T. Vitamin D and the Innate Immune Response. In Vitamin D and the Lung; Litonjua, A.A., Ed.; Humana Press: New York, NY, USA, 2012; pp. 59-84.

144. Campbell, G.R.; Spector, S.A. Autophagy induction by vitamin D inhibits both Mycobacterium tuberculosis and human immunodeficiency virus type 1. Autophagy 2012, 8, 1523-1525.

145. Liu, P.T.; Stenger, S.; Li, H.; Wenzel, L.; Tan, B.H.; Krutzik, S.R.; Ochoa, M.T.; Schauber, J.; $\mathrm{Wu}, \mathrm{K}$; Meinken, C.; et al. Toll-like receptor triggering of a vitamin D-mediated human antimicrobial response. Science 2006, 311, 1770-1773.

146. Sly, L.M.; Lopez, M.; Nauseef, W.M.; Reiner, N.E. 1 1 ,25-Dihydroxyvitamin $\mathrm{D}_{3}$-induced monocyte antimycobacterial activity is regulated by phosphatidylinositol 3-kinase and mediated by the NADPH-dependent phagocyte oxidase. J. Biol. Chem. 2001, 276, 35482-35493.

147. Baeke, F.; Takiishi, T.; Korf, H.; Gysemans, C.; Mathieu, C. Vitamin D: Modulator of the immune system. Curr. Opin. Pharmacol. 2010, 10, 482-496.

148. Pilz, S.; Tomaschitz, A.; März, W.; Drechsler, C.; Ritz, E.; Zittermann, A.; Cavalier, E.; Pieber, T.R.; Lappe, J.M.; Grant, W.B.; et al. Vitamin D, cardiovascular disease and mortality. Clin. Endocrinol. 2011, 75, 575-584.

149. Li, Y.C.; Qiao, G.; Uskokovic, M.; Xiang, W.; Zheng, W.; Kong, J. Vitamin D: A negative endocrine regulator of the renin-angiotensin system and blood pressure. J. Steroid Biochem. Mol. Biol. 2004, 89-90, 387-392.

150. Wolden-Kirk, H.; Overbergh, L.; Christesen, H.T.; Brusgaard, K.; Mathieu, C. Vitamin D and diabetes: Its importance for beta cell and immune function. Mol. Cell. Endocrinol. 2011, 347, 106-120.

151. Russo, A.; Terrasi, M.; Agnese, V.; Santini, D.; Bazan, V. Apoptosis: A relevant tool for anticancer therapy. Ann. Oncol. 2006, 17, vii115-vii123.

152. Dunn, G.P.; Old, L.J.; Schreiber, R.D. The Immunobiology of cancer immunosurveillance and immunoediting. Immunity 2004, 21, 137-148.

153. Kerr, J.F.R.; Winterford, C.M.; Harmon, B.V. Apoptosis. Its significance in cancer and cancer therapy. Cancer 1994, 73, 2013-2026.

154. Blutt, S.E.; McDonnell, T.J.; Polek, T.C.; Weigel, N.L. Calcitriol-induced apoptosis in LNCaP cells is blocked by overexpression of Bcl-2. Endocrinology 2000, 141, 10-17.

155. Deeb, K.K.; Trump, D.L.; Johnson, C.S. Vitamin D signalling pathways in cancer: Potential for anticancer therapeutics. Nat. Rev. Cancer 2007, 7, 684-700.

156. Rohan, J.N.P.; Weigel, N.L. 1Alpha,25-dihydroxyvitamin $\mathrm{D}_{3}$ reduces c-Myc expression, inhibiting proliferation and causing $\mathrm{G} 1$ accumulation in $\mathrm{C} 4-2$ prostate cancer cells. Endocrinology 2009, 150, 2046-2054.

157. Hawk, E.T.; Viner, J.L.; Dannenberg, A.; DuBois, R.N. COX-2 in cancer-A player that's defining the rules. J. Natl. Cancer Inst. 2002, 94, 545-546.

158. Koli, K.; Keski-Oja, J. 1Alpha,25-dihydroxyvitamin $\mathrm{D}_{3}$ and its analogues down-regulate cell invasion-associated proteases in cultured malignant cells. Cell Growth Differ. 2000, 11, 221-229.

159. Peña, C.; García, J.M.; Silva, J.; García, V.; Rodríguez, R.; Alonso, I.; Millán, I.; Salas, C.; de Herreros, A.G.; Muñoz, A.; Bonilla, F. E-cadherin and vitamin D receptor regulation by SNAIL and ZEB1 in colon cancer: Clinicopathological correlations. Hum. Mol. Genet. 2005, 14, 3361-3370. 
160. Grandi, N.C.; Breitling, L.P.; Brenner, H. Vitamin D and cardiovascular disease: Systematic review and meta-analysis of prospective studies. Prev. Med. 2010, 51, 228-233.

161. Vacek, J.L.; Vanga, S.R.; Good, M.; Lai, S.M.; Lakkireddy, D.; Howard, P.A. Vitamin D deficiency and supplementation and relation to cardiovascular health. Am. J. Cardiol. 2012, 109, $359-363$.

162. Wang, T.J.; Pencina, M.J.; Booth, S.L.; Jacques, P.F.; Ingelsson, E.; Lanier, K.; Benjamin, E.J.; D’Agostino, R.B.; Wolf, M.; Vasan, R.S. Vitamin D deficiency and risk of cardiovascular disease. Circulation 2008, 117, 503-511.

163. Eaton, C.B.; Young, A.; Allison, M.A.; Robinson, J.; Martin, L.W.; Kuller, L.H.; Johnson, K.C.; Curb, J.D.; van Horn, L.; McTiernan, A.; et al. Prospective association of vitamin D concentrations with mortality in postmenopausal women: Results from the Women's Health Initiative (WHI). Am. J. Clin. Nutr. 2011, 94, 1471-1478.

164. Anderson, J.L.; May, H.T.; Horne, B.D.; Bair, T.L.; Hall, N.L.; Carlquist, J.F.; Lappé, D.L.; Muhlestein, J.B. Relation of vitamin D deficiency to cardiovascular risk factors, disease status, and incident events in a general healthcare population. Am. J. Cardiol. 2010, 106, 963-968.

165. Sun, Q.; Pan, A.; Hu, F.B.; Manson, J.E.; Rexrode, K.M. 25-Hydroxyvitamin D levels and the risk of stroke. Stroke 2012, 43, 1470-1477.

166. Reid, I.R.; Bolland, M.J. Role of vitamin D deficiency in cardiovascular disease. Heart 2012, 98 , 609-614.

167. Tall, A.R. Exercise to reduce cardiovascular risk-How much is enough? N. Engl. J. Med. 2002, 347, 1522-1524.

168. Wilson, P.W.; D’Agostino, R.B.; Sullivan, L.; Parise, H.; Kannel, W.B. Overweight and obesity as determinants of cardiovascular risk: The Framingham experience. Arch. Intern. Med. 2002, 162, 1867-1872.

169. Wortsman, J.; Matsuoka, L.Y.; Chen, T.C.; Lu, Z.; Holick, M.F. Decreased bioavailability of vitamin D in obesity. Am. J. Clin. Nutr. 2000, 72, 690-693.

170. Drincic, A.T.; Armas, L.A.G.; van Diest, E.E.; Heaney, R.P. Volumetric dilution, rather than sequestration best explains the low vitamin D status of obesity. Obesity 2012, 20, 1444-1448.

171. Burgaz, A.; Orsini, N.; Larsson, S.C.; Wolk, A. Blood 25-hydroxyvitamin D concentration and hypertension: A meta-analysis. J. Hypertens. 2011, 29, 636-645.

172. Witham, M.D.; Nadir, M.A.; Struthers, A.D. Effect of vitamin D on blood pressure: A systematic review and meta-analysis. J. Hypertens. 2009, 27, 1948-1954.

173. Wu, S.H.; Ho, S.C.; Zhong, L. Effects of vitamin D supplementation on blood pressure. South Med. J. 2010, 103, 729-737.

174. Elamin, M.B.; Abu Elnour, N.O.; Elamin, K.B.; Fatourechi, M.M.; Alkatib, A.A.; Almandoz, J.P.; Liu, H.; Lane, M.A.; Mullan, R.J.; Hazem, A.; et al. Vitamin D and cardiovascular outcomes: A systematic review and meta-analysis. J. Clin. Endocrinol. Metab. 2011, 96, 1931-1942.

175. Krause, R.; Bühring, M.; Hopfenmüller, W.; Holick, M.F.; Sharma, A.M. Ultraviolet B and blood pressure. Lancet 1998, 352, 709-710.

176. Fitzpatrick, L.; Bilezikian, J.; Silverberg, S. Parathyroid hormone and the cardiovascular system. Curr. Osteoporos. Rep. 2008, 6, 77-83. 
177. Mitri, J.; Muraru, M.D.; Pittas, A.G. Vitamin D and type 2 diabetes: A systematic review. Eur. J. Clin. Nutr. 2011, 65, 1005-1015.

178. Pittas, A.G.; Dawson-Hughes, B.; Li, T.; van Dam, R.M.; Willett, W.C.; Manson, J.E.; Hu, F.B. Vitamin D and calcium intake in relation to type 2 diabetes in women. Diabetes Care 2006, 29, $650-656$.

179. Holick, M.F. Nutrition: D-iabetes and D-eath D-efying vitamin D. Nat. Rev. Endocrinol. 2012, 8, 388-390.

180. Deleskog, A.; Hilding, A.; Brismar, K.; Hamsten, A.; Efendic, S.; Östenson, C.G. Low serum 25-hydroxyvitamin D level predicts progression to type 2 diabetes in individuals with prediabetes but not with normal glucose tolerance. Diabetologia 2012, 55, 1668-1678.

181. Antico, A.; Tampoia, M.; Tozzoli, R.; Bizzaro, N. Can supplementation with vitamin D reduce the risk or modify the course of autoimmune diseases? A systematic review of the literature. Autoimmun. Rev. 2012, 12, 127-136.

182. Ponsonby, A.-L.; McMichael, A.; van der Mei, I. Ultraviolet radiation and autoimmune disease: Insights from epidemiological research. Toxicology 2002, 181-182, 71-78.

183. Peyrin-Biroulet, L.; Oussalah, A.; Bigard, M.-A. Crohn's disease: The hot hypothesis. Med. Hypotheses 2009, 73, 94-96.

184. Vieira, V.M.; Hart, J.E.; Webster, T.F.; Weinberg, J.; Puett, R.; Laden, F.; Costenbader, K.H.; Karlson, E.W. Association between residences in U.S. northern latitudes and rheumatoid arthritis: A spatial analysis of the Nurses' Health Study. Environ. Health Perspect. 2010, 118, 957-961.

185. Mohr, S.; Garland, C.; Gorham, E.; Garland, F. The association between ultraviolet B irradiance, vitamin D status and incidence rates of type 1 diabetes in 51 regions worldwide. Diabetologia 2008, 51, 1391-1398.

186. Munger, K.L.; Levin, L.I.; Hollis, B.W.; Howard, N.S.; Ascherio, A. Serum 25-hydroxyvitamin D levels and risk of multiple sclerosis. JAMA 2006, 296, 2832-2838.

187. Burton, J.M.; Kimball, S.; Vieth, R.; Bar-Or, A.; Dosch, H.-M.; Cheung, R.; Gagne, D.; D’Souza, C.; Ursell, M.; O'Connor, P. A phase I/II dose-escalation trial of vitamin D3 and calcium in multiple sclerosis. Neurology 2010, 74, 1852-1859.

188. Pierrot-Deseilligny, C.; Rivaud-Pechoux, S.; Clerson, P.; de Paz, R.; Souberbielle, J.C. Relationship between 25-OH-D serum level and relapse rate in multiple sclerosis patients before and after vitamin D supplementation. Ther. Adv. Neurol. Disord. 2012, 5, 187-198.

189. Sørensen, I.M.; Joner, G.; Jenum, P.A.; Eskild, A.; Torjesen, P.A.; Stene, L.C. Maternal serum levels of 25-hydroxy-vitamin D during pregnancy and risk of type 1 diabetes in the offspring. Diabetes 2012, 61, 175-178.

190. Hyppönen, E.; Läärä, E.; Reunanen, A.; Järvelin, M.-R.; Virtanen, S.M. Intake of vitamin D and risk of type 1 diabetes: A birth-cohort study. Lancet 2001, 358, 1500-1503.

191. Stene, L.C.; Ulriksen, J.; Magnus, P.; Joner, G. Use of cod liver oil during pregnancy associated with lower risk of Type I diabetes in the offspring. Diabetologia 2000, 43, 1093-1098.

192. Merlino, L.A.; Curtis, J.; Mikuls, T.R.; Cerhan, J.R.; Criswell, L.A.; Saag, K.G. Vitamin D intake is inversely associated with rheumatoid arthritis: Results from the Iowa Women's Health Study. Arthritis Rheum. 2004, 50, 72-77. 
193. Vogel, A.; Strassburg, C.P.; Manns, M.P. Genetic association of vitamin D receptor polymorphisms with primary biliary cirrhosis and autoimmune hepatitis. Hepatology 2002, 35, 126-131.

194. Ban, Y.; Taniyama, M.; Ban, Y. Vitamin D receptor gene polymorphism is associated with Graves' disease in the Japanese population. J. Clin. Endocrinol. Metab. 2000, 85, 4639-4643.

195. Škrabić, V.; Zemunik, T.; Šitum, M.; Terzić, J. Vitamin D receptor polymorphism and susceptibility to type 1 diabetes in the Dalmatian population. Diabetes Res. Clin. Pract. 2003, 59, 31-35.

196. Garcia-Lozano, J.R.; Gonzalez-Escribano, M.F.; Valenzuela, A.; Garcia, A.; Núñez-Roldán, A. Association of vitamin D receptor genotypes with early onset rheumatoid arthritis. Eur. J. Immunogenet. 2001, 28, 89-93.

197. Gómez-Vaquero, C.; Fiter, J.; Enjuanes, A.; Nogués, X.; Díez-Pérez, A.; Nolla, J.M. Influence of the BsmI polymorphism of the vitamin D receptor gene on rheumatoid arthritis clinical activity. J. Rheumatol. 2007, 34, 1823-1826.

198. Yamshchikov, A.V.; Desai, N.S.; Blumberg, H.M.; Ziegler, T.R.; Tangpricha, V. Vitamin D for treatment and prevention of infectious diseases: A systematic review of randomized controlled trials. Endocr. Pract. 2009, 15, 438-449.

199. Battersby, A.J.; Kampmann, B.; Burl, S. Vitamin D in early childhood and the effect on immunity to mycobacterium tuberculosis. Clin. Dev. Immunol. 2012, 2012, 430972.

200. Hart, P.D. Chemotherapy of tuberculosis; research during the past 100 years. Br. Med. J. 1946, 2 , 805-849.

201. Everett, D. On the use of cod-liver oil in tubercular disease. Prov. Med. Surg. J. 1846, 10, 538-539.

202. The Nobel Prize in Physiology or Medicine 1903. Niels Ryberg Finsen. Available online: http://www.nobelprize.org/nobel_prizes/medicine/laureates/1903/(accessed on 8 September 2012).

203. Rider, A.A. Elmer Verner McCollum—A biographical sketch (1879-1967). J. Nutr. 1970, 100, 1-10.

204. Dowling, G.B.; Thomas, E.W.; Wallace, H.J. Lupus Vulgaris treated with Calciferol. Proc. $R$. Soc. Med. 1946, 39, 225-227.

205. Phelan, J.J. Calciferol in pulmonary tuberculosis. Lancet 1947, 1, 764.

206. Martineau, A.R. Old wine in new bottles: Vitamin D in the treatment and prevention of tuberculosis. Proc. Nutr. Soc. 2012, 71, 84-89.

207. Sasidharan, P.K.; Rajeev, E.; Vijayakumari, V. Tuberculosis and vitamin D deficiency. J. Assoc. Physicians India 2002, 50, 554-558.

208. Wilkinson, R.J.; Llewelyn, M.; Toossi, Z.; Patel, P.; Pasvol, G.; Lalvani, A.; Wright, D.; Latif, M.; Davidson, R.N. Influence of vitamin D deficiency and vitamin D receptor polymorphisms on tuberculosis among Gujarati Asians in west London: A case-control study. Lancet 2000, 355, 618-621.

209. Nnoaham, K.E.; Clarke, A. Low serum vitamin D levels and tuberculosis: A systematic review and meta-analysis. Int. J. Epidemiol. 2008, 37, 113-119.

210. Ganmaa, D.; Giovannucci, E.; Bloom, B.R.; Fawzi, W.; Burr, W.; Batbaatar, D.; Sumberzul, N.; Holick, M.F.; Willett, W.C. Vitamin D, tuberculin skin test conversion, and latent tuberculosis in 
Mongolian school-age children: A randomized, double-blind, placebo-controlled feasibility trial. Am. J. Clin. Nutr. 2012, 96, 391-396.

211. Martineau, A.R.; Wilkinson, R.J.; Wilkinson, K.A.; Newton, S.M.; Kampmann, B.; Hall, B.M.; Packe, G.E.; Davidson, R.N.; Eldridge, S.M.; Maunsell, Z.J.; et al. A single dose of vitamin D enhances immunity to mycobacteria. Am. J. Respir. Crit. Care Med. 2007, 176, 208-213.

212. Nursyam, E.W.; Amin, Z.; Rumende, C.M. The effect of vitamin D as supplementary treatment in patients with moderately advanced pulmonary tuberculous lesion. Acta Med. Indones. 2006, $38,3-5$.

213. Martineau, A.R.; Timms, P.M.; Bothamley, G.H.; Hanifa, Y.; Islam, K.; Claxton, A.P.; Packe, G.E.; Moore-Gillon, J.C.; Darmalingam, M.; Davidson, R.N.; et al. High-dose vitamin $\mathrm{D}_{3}$ during intensive-phase antimicrobial treatment of pulmonary tuberculosis: A double-blind randomised controlled trial. Lancet 2011, 377, 242-250.

214. Morcos, M.M.; Gabr, A.A.; Samuel, S.; Kamel, M.; el Baz, M.; el Beshry, M.; Michail, R.R. Vitamin D administration to tuberculous children and its value. Boll. Chim. Farm. 1998, 137, $157-164$.

215. Coussens, A.K.; Wilkinson, R.J.; Hanifa, Y.; Nikolayevskyy, V.; Elkington, P.T.; Islam, K.; Timms, P.M.; Venton, T.R.; Bothamley, G.H.; Packe, G.E.; et al. Vitamin D accelerates resolution of inflammatory responses during tuberculosis treatment. Proc. Natl. Acad. Sci. USA 2012, 109, doi:10.1073/pnas.1216789109.

216. Wejse, C.; Gomes, V.F.; Rabna, P.; Gustafson, P.; Aaby, P.; Lisse, I.M.; Andersen, P.L.; Glerup, H.; Sodemann, M. Vitamin D as supplementary treatment for tuberculosis. Am. J. Respir. Crit. Care Med. 2009, 179, 843-850.

217. Jorde, R.; Witham, M.; Janssens, W.; Rolighed, L.; Borchhardt, K.; de Boer, I.H.; Grimnes, G.; Hutchinson, M.S. Vitamin D supplementation did not prevent influenza-like illness as diagnosed retrospectively by questionnaires in subjects participating in randomized clinical trials. Scand. J. Infect. Dis. 2012, 44, 126-132.

218. Urashima, M.; Segawa, T.; Okazaki, M.; Kurihara, M.; Wada, Y.; Ida, H. Randomized trial of vitamin D supplementation to prevent seasonal influenza A in schoolchildren. Am. J. Clin. Nutr. 2010, 91, 1255-1260.

219. Cannell, J.J.; Vieth, R.; Umhau, J.C.; Holick, M.F.; Grant, W.B.; Madronich, S.; Garland, C.F.; Giovannucci, E. Epidemic influenza and vitamin D. Epidemiol. Infect. 2006, 134, 1129-1140.

220. Hope-Simpson, R.E. The role of season in the epidemiology of influenza. J. Hyg. (Lond.) 1981, $86,35-47$.

221. Ginde, A.; Mansbach, J.M.; Camargo, C.A. Association between serum 25-hydroxyvitamin D level and upper respiratory tract infection in the third national health and nutrition examination survey. Arch. Intern. Med. 2009, 169, 384-390.

222. Laaksi, I.; Ruohola, J.-P.; Tuohimaa, P.; Auvinen, A.; Haataja, R.; Pihlajamäki, H.; Ylikomi, T. An association of serum vitamin $\mathrm{D}$ concentrations $<40 \mathrm{nmol} / \mathrm{L}$ with acute respiratory tract infection in young Finnish men. Am. J. Clin. Nutr. 2007, 86, 714-717.

223. Wayse, V.; Yousafzai, A.; Mogale, K.; Filteau, S. Association of subclinical vitamin D deficiency with severe acute lower respiratory infection in Indian children under 5 y. Eur. J. Clin. Nutr. 2004, 58, 563-567. 
224. Aloia, J.F.; Li-Ng, M. Re: Epidemic influenza and vitamin D. Epidemiol. Infect. 2007, 135, 1095-1096.

225. Avenell, A.; Cook, J.A.; MacLennan, G.S.; MacPherson, G.C. Vitamin D supplementation to prevent infections: A sub-study of a randomised placebo-controlled trial in older people (RECORD trial, ISRCTN 51647438). Age Ageing 2007, 36, 574-577.

226. Li-Ng, M.; Aloia, J.F.; Pollack, S.; Cunha, B.A.; Mikhail, M.; Yeh, J.; Berbari, N. A randomized controlled trial of vitamin D3 supplementation for the prevention of symptomatic upper respiratory tract infections. Epidemiol. Infect. 2009, 137, 1396-1404.

227. Roth, D.E.; Jones, A.B.; Prosser, C.; Robinson, J.L.; Vohra, S. Vitamin D receptor polymorphisms and the risk of acute lower respiratory tract infection in early childhood. $J$. Infect. Dis. 2008, 197, 676-680.

228. Hewison, M. An update on vitamin D and human immunity. Clin. Endocrinol. 2012, 76, $315-325$.

229. Brown, S.D.; Calvert, H.H.; Fitzpatrick, A.M. Vitamin D and asthma. Dermato-Endocrinol. 2012, 4, 137-145.

230. Camargo, C.A., Jr.; Rifas-Shiman, S.L.; Litonjua, A.A.; Rich-Edwards, J.W.; Weiss, S.T.; Gold, D.R.; Kleinman, K.; Gillman, M.W. Maternal intake of vitamin D during pregnancy and risk of recurrent wheeze in children at 3 y of age. Am. J. Clin. Nutr. 2007, 85, 788-795.

231. Camargo, C.A., Jr.; Ingham, T.; Wickens, K.; Thadhani, R.; Silvers, K.M.; Epton, M.J.; Town, G.I.; Pattemore, P.K.; Espinola, J.A.; Crane, J. Cord-blood 25-hydroxyvitamin D levels and risk of respiratory infection, wheezing, and asthma. Pediatrics 2011, 127, e180-e187.

232. Carroll, K.N.; Gebretsadik, T.; Larkin, E.K.; Dupont, W.D.; Liu, Z.; van Driest, S.; Hartert, T.V. Relationship of maternal vitamin $\mathrm{D}$ level with maternal and infant respiratory disease. Am. J. Obstet. Gynecol. 2011, 205, e211-e217.

233. Devereux, G.; Litonjua, A.A.; Turner, S.W.; Craig, L.C.; McNeill, G.; Martindale, S.; Helms, P.J.; Seaton, A.; Weiss, S.T. Maternal vitamin D intake during pregnancy and early childhood wheezing. Am. J. Clin. Nutr. 2007, 85, 853-859.

234. Erkkola, M.; Kaila, M.; Nwaru, B.I.; Kronberg-Kippila, C.; Ahonen, S.; Nevalainen, J.; Veijola, R.; Pekkanen, J.; Ilonen, J.; Simell, O.; et al. Maternal vitamin D intake during pregnancy is inversely associated with asthma and allergic rhinitis in 5-year-old children. Clin. Exp. Allergy 2009, 39, 875-882.

235. Gale, C.R.; Robinson, S.M.; Harvey, N.C.; Javaid, M.K.; Jiang, B.; Martyn, C.N.; Godfrey, K.M.; Cooper, C. Maternal vitamin D status during pregnancy and child outcomes. Eur. J. Clin. Nutr. 2008, 62, 68-77.

236. Rothers, J.; Wright, A.L.; Stern, D.A.; Halonen, M.; Camargo, C.A., Jr. Cord blood 25-hydroxyvitamin D levels are associated with aeroallergen sensitization in children from Tucson, Arizona. J. Allergy Clin. Immunol. 2011, 128, 1093-1099.

237. Chinellato, I.; Piazza, M.; Sandri, M.; Peroni, D.; Piacentini, G.; Boner, A.L. Vitamin D serum levels and markers of asthma control in Italian children. J. Pediatr. 2011, 158, 437-441.

238. Chinellato, I.; Piazza, M.; Sandri, M.; Peroni, D.G.; Cardinale, F.; Piacentini, G.L.; Boner, A.L. Serum vitamin D levels and exercise-induced bronchoconstriction in children with asthma. Eur. Respir. J. 2011, 37, 1366-1370. 
239. Searing, D.A.; Zhang, Y.; Murphy, J.R.; Hauk, P.J.; Goleva, E.; Leung, D.Y. Decreased serum vitamin D levels in children with asthma are associated with increased corticosteroid use. J. Allergy Clin. Immunol. 2010, 125, 995-1000.

240. Heaney, R.P.; Davies, K.M.; Chen, T.C.; Holick, M.F.; Barger-Lux, M.J. Human serum 25-hydroxycholecalciferol response to extended oral dosing with cholecalciferol. Am. J. Clin. Nutr. 2003, 77, 204-210.

241. Godar, D.E.; Pope, S.J.; Grant, W.B.; Holick, M.F. Solar UV doses of adult Americans and vitamin D(3) production. Dermato-Endocrinol. 2011, 3, 243-250.

242. Pietras, S.M.; Obayan, B.K.; Cai, M.H.; Holick, M.F. Vitamin D2 treatment for vitamin D deficiency and insufficiency for up to 6 years. Arch. Intern. Med. 2009, 169, 1806-1808.

243. Jones, G. Pharmacokinetics of vitamin D toxicity. Am. J. Clin. Nutr. 2008, 88, 582S-586S.

244. Taylor, A.B.; Stern, P.H.; Bell, N.H. Abnormal regulation of circulating 25-hydroxyvitamin D in the Williams syndrome. N. Engl. J. Med. 1982, 306, 972-975.

245. Schlingmann, K.P.; Kaufmann, M.; Weber, S.; Irwin, A.; Goos, C.; John, U.; Misselwitz, J.; Klaus, G.; Kuwertz-Bröking, E.; Fehrenbach, H.; et al. Mutations in CYP24A1 and Idiopathic Infantile Hypercalcemia. N. Engl. J. Med. 2011, 365, 410-421.

246. Eyles, D.W.; Burne, T.H.J.; McGrath, J.J. Vitamin D, effects on brain development, adult brain function and the links between low levels of vitamin D and neuropsychiatric disease. Front. Neuroendocrinol. 2012, in press.

(C) 2013 by the authors; licensee MDPI, Basel, Switzerland. This article is an open access article distributed under the terms and conditions of the Creative Commons Attribution license (http://creativecommons.org/licenses/by/3.0/). 